\title{
Bir Kısır Döngü: Dünyada ve Türkiye’de Çocuk İşçiliği ve İşsizlik*
}

\section{A Vicious Circle: Child Labor and Unemployment in the World and Turkey}

\author{
Mustafa Çöpoğlu a,*** \\ ${ }^{a}$ Dr., Doğu Marmara Kalkınma Ajansı, Genel Sekreterlik, 41050, Kocaeli/Türkiye. \\ ORCID: 0000-0003-3320-0845
}

\section{MAKALE BİLGİSI}

\section{Makale Geçmişi:}

Başvuru tarihi: 20 Şubat 2018

Düzeltme tarihi: 01 Nisan 2018

Kabul tarihi: 05 Nisan 2018

\section{Anahtar Kelimeler:}

Çocuk İşçiliği

Çalışan Çocuklar

Yoksulluk

Çocuk İşçiliğiyle Mücadele

\section{ART ICLE INFO}

\section{Article history:}

Received 20 February 2018

Received in revised form 01 April 2018

Accepted 05 April 2018

\section{Keywords:}

Child Labour

Working Children

Poverty

Combatting Child Labour
ÖZ

Günümüzde müdahale edilmesi gerekli alanların başında gelen çocuk işçiliği; çocukların fiziki, psikolojik, sosyolojik gelişimlerini olumsuz etkilemesi sebebiyle önemlidir. Uluslararası Çalışma Örgütü'nün 2017 verilerine göre, 5-17 yaş grubundaki 151,6 milyon çocuk, çalışmaktadır. Çocuk işçiliğinin sebebi işsizlik ve işsizliğin bir sonucu olan yoksulluktur. Türkiye İstatistik Kurumu'nun 2006 tarihli Çocuk İşü̈cü Anketi sonuçlarına göre, 6-17 yaş gurubundaki çocukların çalışma nedenlerinin başında \% 51,1 ile "hane halkı gelirine katkıda bulunmak" gelmektedir. Ailelerinin sosyo-ekonomik durumları kötü olduğu için çalışmak zorunda kalan çocuklar; çalışma hayatında meslek öğreniminden ziyade gelir sağlamak için yer almaktadırlar. Anılan olumsuzlukların giderilmesine katkı sağlamayı amaçlayan bu çalışmada; çocuk işçiliğinin dünyada ve Türkiye'deki mevcut durumu analiz edilecek olup, çocuk işçiliğini önlemeye yönelik ulusal ve uluslararası müdahale yöntemlerinden bahsedilerek politikalar geliştirilmesine yönelik öneriler sunulacaktır.

\section{A B S T R A C T}

Being at the forefront field that must be intervened, child labor is important because it negatively affects children's physical, psychological and sociological development. According to the International Labour Office's 2017 data, 151.6 million children aged 5 to 17 years are working as child labourers. The cause of child labor is unemployment and also the poverty which is a consequence of unemployment. According to The Child Labour Survey results that was made by the Turkey Statistical Institute in 2006; the leading working cause of the children between is "to contribute to the household income" with a percentage of $51.1 \%$. Children, who have to work because of their family's bad socio-economic situation, are involved in working life to provide income rather than to learn a profession. In this study aiming to contribute to the elimination of the identified negative situations, the current situation of child labour in the world and in Turkey is going to be analysed and by mentioning national and international intervention methods to prevent child labour, proposals for the development of policies will be presented.

\section{Giriş}

Çocuk işçiliği gelişmekte olan ülkelerin olduğu gibi gelişmiş ülkelerin de en önemli sorunlarındandır. Hem gelişmiş ülkelerde hem de gelişmekte olan ülkelerde hükümetler, işçi ve işveren kuruluşları ve sivil toplum örgütleri çocuk işçiliğine karşı mücadele etmektedir. Tüm dünyada çocuk ve işçilik yan yana gelmesi istenmeyen iki kavramdır.

Toplumda çocuk işçiliği ile ilgili çelişkili bir tavır sergilenmektedir. Söylemlerde çocuk işçiliğine karşıt bir tutum dile getirilse de günümüzde çok sayıda çocuk çalışmaya devam etmektedir.

Çocuk işçiliği her şeyden öte bir insan hakları ihlalidir. Çünkü kendi seçimleri olmadan zorla veya zorunlu olarak çalışan çocuklar, en temel hakları olan; çocukluklarını yaşamak, sağlıklı beslenmek, eğitim imkânlarından yararlanmak kısaca geleceğe hazırlanmak haklarından mahrum kalmaktadırlar.

* Bu çalışma, 1998 yılında İstanbul Üniversitesi Sosyal Bilimler Enstitüsü tarafindan kabul edilen “Çocuk İşçiliği” adlı Doktora tezinden türetilmiştir.

** Sorumlu yazar/Corresponding author.

e-posta: mcopoglu@gmail.com 
Çocuk işçiliği, önemli sonuçlarının uzun vadede ortaya çıktığı bir problemdir. Çocuk işçiliği, hem mikro hem de makro seviyede, gelecekte oluşabilecek farklı sorunların potansiyel kaynağıdır. Genel ve mesleki eğitimden yoksun olarak, niteliksiz bir şekilde, sadece ucuz-uysal olduğu için çocuk işgücü istihdam etme politikası, gelecekte hem işletmeler hem de ülkeler için geri dönüşü olmayan bir hatadır. Zaten kıt olan yetişmiş insan kaynağı bu şekilde, niteliksiz-kıt olarak, daha az bulunur bir sermaye olacaktır.

Çocuk işçiliği gelecekte toplumlar için niteliksizliği, düşük verimi, işsizliği ve daha birçok sosyal ve ekonomik sorunu beraberinde getirecektir. İnsanlık tarihince, çocuk işçiliği gündeme gelecektir. Çünkü ucuz-uysal çocuk emeğinden faydalanmak isteyenlerin olabileceği gibi çeşitli sebeplerle emeğini arz etmek isteyen çocuklar da olacaktır. Yine günümüzde olduğu gibi, bazı sebeplerin arkasına sığınıp çocuk işçiliğini meşru göstermeye çalışanlar da bulunacaktır. Onun için çocuk işçiliği probleminin çözülmesi, tekrarlanmayacağı anlamına gelmemektedir. Önce problemi çözmek sonra da çocuk işçiliği probleminin tekrarlanmaması için gerekli önlemleri almak gereklidir. Bilinmelidir ki korumak tedavi etmekten daha kolay ve daha az maliyetlidir.

Çocuk işçiliğinin hiç şüphesiz pek çok nedeni vardır. $\mathrm{Bu}$ nedenlerin başlıcaları; işsizlik ve yoksulluktur.

$\mathrm{Bu}$ çalışmanın amacı; çocuk işçiliğinin en temel nedeni olan yoksulluk faktöründen yola çıkarak Türkiye ve Dünya'daki çocuk işçiliğinin ne boyutta olduğunu ortaya koymaktır.

Çalışmanın birinci bölümünde, çocuk işçiliğinin başlıca sebeplerinden yoksulluk ve işsizlik incelenmiş olup, Türkiye ve dünyadaki çocuk nüfusu ve işgücüyle karşılaştırmalı veriler analiz edilmektedir. Çalışmanın ikinci bölümünde ise çocuk işçiliği ile yapılması gereken ulusal ve uluslararası mücadele yöntemleri yer almaktadır. Sonuç bölümünde ise çocuk işgücünün önlenmesine yönelik önerilere yer verilmiştir.

\section{2. İşsizlik ve Yoksulluk}

Çocuk istihdamına sebep olan en önemli faktörlerden biri yoksulluktur. Bütün araştırma ve çalışmalar çocuk işçiliğinin temel nedenini yoksulluk olarak göstermektedir (ÇSGB, 2017: 15). Yoksul aileler kazançlarının önemli sayılabilecek kısmını temel gıda harcamalarında kullanmaktadırlar. Dolayısıyla çocuk emeği yaşamı sürdürme açısından da belirleyici bir faktördür. (Tunçcan, 1999: 10).

Ailelerin ekonomik durumları hane halkında bulunan çocukların iş hayatında yer almalarında önemli bir rol oynamaktadır. Ekonomik durumu iyi olmayan aileler için eğitim geri planda kalmakta, çocukların ev ekonomisine katkıda bulunmaları için fiziksel, ruhsal durumlarına bakılmaksızın çocuklar çalıştırılmaktadırlar (İlik, 1994: 4). Çocuk işçiliğinin nedenlerinde; yoksulluk, aile desteğinden yoksun kalma, gelenekler, göç, eşitsizlik gibi faktörler rol oynamaktadır (TÜİK, 2012: III). Yoksul ailelerde çocuğun çalışması, evde kardeşlerinin bakımını üstlenmesi, aile işçisi olarak ücretsiz çalışması aile bütçesinde katkı olarak görülmektedir.

TUİK 2016 yılı gelire dayalı yoksulluk verilerine göre Türkiye'de nüfusun \% 28,7'si yaklaşık 22,8 milyonu yoksulluk içerisinde yaşamaktadır. $\mathrm{Bu}$ sebeple birçok aile, hane halkı gelirini artırmak için çocukların çalışmasına ihtiyaç duymaktadır. Bu sebeple, çocuk işçiler ya hiç okula gidememekte ya da okulu bırakmak zorunda kalmaktadırlar. Çalışan çocukların bir bölümü tarım sektöründe ucuz işgücü olarak çalışmaktadırlar. Bazıları ise göçmen ailelerin çocukları olup bu aileler kötü yaşam koşullarından dolayı eğitim ve sağlik hizmetlerine de erişememektedirler. Sokakta yaşamaya itilen çocuklar ise sokak satıcıları olarak karşımıza çıkmaktadır. Kız çocukları açısından beklenti ise erken evlilik olup kadın ve kız çocuklarının işgücüne katkısı ise genel olarak kayıt dışıdır. Kız çocuklarının yaptığ büyük çoğunluğu evde yapılan ücretsiz ev işleri şeklinde karşımıza çıkmaktadır (UNICEF, 2006).

Şekil 1. 6-17 Yaş Grubu Çocukların Okula Devam ve Çalışma Durumuna Göre Dağılımı, 2012

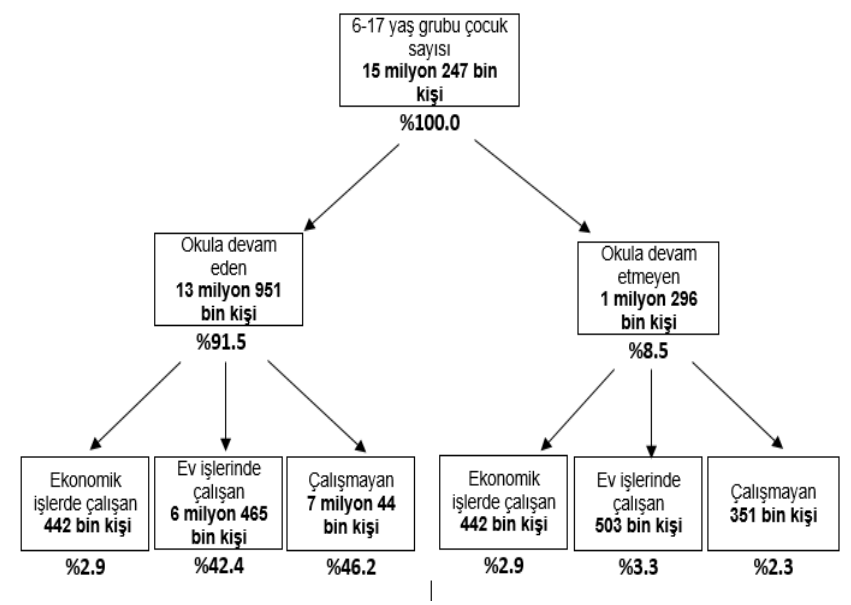

Kaynak: TÜİK (2012)

6-17 yaş grubundaki çocuklardan \% 2,9'u ekonomik bir işte çalışırken okula devam etmektedir ve yine \% 2,9'u ekonomik işlerde çalışmakta ve okula devam edememektedir. \% 3,3'ü okula devam etmemekte, ev işlerinde çalışmaktadır. Dolayısıyla ekonomik koşullar çocukların okula devam etme veyahut devam etmeme konusunda önem arz etmektedir (Şekil 1).

Geçmiş yıllara göre kıyasla 2006 yılında okula devam etmeyen 2 milyon 492 bin çocuğun \% 26,3'ü ekonomik işlerde, 2012 yılında ise okula devam etmeyen 1 milyon 296 bin çocuğun \% 34,5'i ekonomik işlerde çalışmaktadır (TÜİK, 2012).

Tablo 1a. Cinsiyet, Yerleşim Yeri ve Yaş Grubuna Göre Okula Devam Etmeme Nedenlerinin Dağılımı, 2006, (\%)

\begin{tabular}{ccccc}
\hline $\begin{array}{c}\text { Yerleşim } \\
\text { yeri, } \\
\text { Cinsiyet ve } \\
\text { Yaş Grubu }\end{array}$ & $\begin{array}{c}\text { Yaşının } \\
\text { uygun } \\
\text { olmaması }\end{array}$ & $\begin{array}{c}\text { Hasta } \\
\text { veya } \\
\text { özürlü } \\
\text { olması }\end{array}$ & $\begin{array}{c}\text { Okulun } \\
\text { çok } \\
\text { uzak } \\
\text { olması }\end{array}$ & $\begin{array}{c}\text { Okul } \\
\text { masraflarını } \\
\text { karşlayamama }\end{array}$ \\
\hline Toplam & 12.0 & 5.3 & 3.1 & 22.4 \\
Kent & 13.5 & 6.2 & 0.9 & 19.9 \\
Kır & 10.4 & 4.4 & 5.3 & 25.0 \\
Erkek & 14.2 & 7.0 & 1.7 & 18.9 \\
Kadın & 10.3 & 4.2 & 4.2 & 25.0 \\
$6-14$ & 30.4 & 9.3 & 4.6 & 20.5 \\
$15-17$ & 0.7 & 2.9 & 2.3 & 23.6 \\
\hline
\end{tabular}


Tablo 1b. Cinsiyet, Yerleşim Yeri ve Yaş Grubuna Göre Okula Devam Etmeme Nedenlerinin Dağılımı, 2006

\begin{tabular}{|c|c|c|c|c|}
\hline $\begin{array}{c}\text { Yerleşim } \\
\text { yeri, } \\
\text { Cinsiyet ve } \\
\text { Yaş Grubu }\end{array}$ & \multicolumn{2}{|c|}{$\begin{array}{l}\text { Ailenin okula } \\
\text { gitmesine izin } \\
\text { vermemesi }\end{array}$} & $\begin{array}{l}\text { Derslerde başarısız } \\
\text { olması/okula ilgi } \\
\text { duymaması }\end{array}$ & $\begin{array}{c}\text { Okula } \\
\text { gitmenin } \\
\text { yararına } \\
\text { inanmamas } \\
1\end{array}$ \\
\hline Toplam & 14.0 & & 15.4 & 5.2 \\
\hline Kent & 8.1 & & 17.2 & 6.0 \\
\hline Kir & 20.0 & & 13.5 & 4.4 \\
\hline Erkek & 4.1 & & 22.1 & 7.5 \\
\hline Kadın & 20.9 & & 10.7 & 3.6 \\
\hline $6-14$ & 13.9 & & 6.7 & 2.9 \\
\hline $15-17$ & 14.0 & & 20.7 & 6.7 \\
\hline $\begin{array}{l}\text { Yerleşim } \\
\text { yeri, } \\
\text { Cinsiyet ve } \\
\text { Yaş Grubu }\end{array}$ & $\begin{array}{l}\text { Okulun } \\
\text { emniyetli } \\
\text { olmamas1 }\end{array}$ & $\begin{array}{c}\text { Çalışmak } \\
\text { zorunda } \\
\text { olması }\end{array}$ & $\begin{array}{cc} & \text { Hanehalkı } \\
\mathrm{k} & \text { fertlerine ev } \\
\text { a ş̧lerinde yardım } \\
\text { etmek zorunda } \\
\text { olması }\end{array}$ & Diğer \\
\hline Toplam & 0.6 & 3.2 & 1.4 & 17.5 \\
\hline Kent & 0.6 & 3.9 & 1.3 & 22.4 \\
\hline Kir & 0.6 & 2.4 & 1.6 & 12.4 \\
\hline Erkek & 0.5 & 4.5 & 0.6 & 19.2 \\
\hline Kadın & 0.7 & 2.3 & 2.0 & 16.3 \\
\hline $6-14$ & 0.8 & 2.3 & 0.6 & 8.0 \\
\hline $15-17$ & 0.5 & 3.7 & 1.9 & 23.2 \\
\hline
\end{tabular}

Kaynak: TÜİK (2006)

Tablo 1 incelendiğinde, 2006 sonuçlarına göre okula devam etmeyen (okulu terk eden veya hiç okula gitmemiş olan) çocukların, neden okula devam etmedikleri incelendiğinde toplamda "okul masraflarını karşılayamama" \% 22,4 ile birinci sırada yer almaktadır.

Çalışmak zorunda olduğu için okula devam etmeyen erkek çocukların oranı \% 4,5 iken, kız çocuklar için bu oran \% 2,3'dür.

Tablo 2. Yaş Grubu, Cinsiyet ve Çalışma Nedenine Göre Ekonomik Faaliyetlerde Çalışan Çocuklar, 2012, \%

\begin{tabular}{|c|c|c|c|}
\hline & \multicolumn{3}{|c|}{ Çalışma Nedeni } \\
\hline \multirow{3}{*}{$\begin{array}{l}\text { Yaş grubu ve } \\
\text { cinsiyet }\end{array}$} & Hanehalk1 & Hanehalkının & İş öğrenmek, \\
\hline & gelirine katk1da & ekonomik faaliyetine & e meslek sahibi \\
\hline & bulunmak & yardımcı olmak & \\
\hline Toplam & 41.4 & 28.7 & 15.2 \\
\hline $6-14$ & 29.8 & 48.6 & 5.5 \\
\hline $15-17$ & 46.9 & 19.0 & 20.1 \\
\hline Kent & 45.5 & 10.5 & 25.3 \\
\hline $6-14$ & 39.2 & 29.1 & 13.9 \\
\hline $15-17$ & 46.9 & 5.9 & 28.3 \\
\hline Kir & 37.9 & 43.4 & 7.1 \\
\hline $6-14$ & 26.2 & 56.1 & 2.3 \\
\hline \multirow[t]{2}{*}{$15-17$} & 47.0 & 33.7 & 10.8 \\
\hline & \multicolumn{3}{|c|}{ Çalışma Nedeni } \\
\hline $\begin{array}{l}\text { Yaş grubu ve } \\
\text { cinsiyet }\end{array}$ & Ailenin isteği & $\begin{array}{l}\text { Kendi ihtiyaçlarını } \\
\text { karşılamak }\end{array}$ & Diğer \\
\hline Toplam & 6.0 & 6.8 & 1.8 \\
\hline $6-14$ & 12.0 & 3.1 & 1.0 \\
\hline $15-17$ & 3.0 & 8.7 & 2.2 \\
\hline Kent & 4.5 & 11.0 & 3.0 \\
\hline $6-14$ & 8.9 & 7.6 & 0.0 \\
\hline $15-17$ & 3.1 & 11.8 & 3.7 \\
\hline Kir & 7.3 & 3.4 & 0.8 \\
\hline $6-14$ & 13.1 & 1.4 & 0.9 \\
\hline $15-17$ & 2.9 & 5.0 & 0.4 \\
\hline
\end{tabular}

Kaynak: TÜİK (2012)
Tablo 2'de çalışma nedenleri yaş gruplarına göre incelendiğinde 6-14 yaş grubunda ilk sırayı "hane halkı gelirine katkıda bulunmak" yer almaktadır. İkinci sırada ise "hane halkının ekonomik faaliyetlerine yardımcı olmak" bulunmaktadır.

6-17 yaş grubundaki çocukların çalışma nedenlerine bakıldığında \%41,4 ile "hane halkı gelirine katkıda bulunmak" birinci sırada yer almaktadır. Ailesinin isteği ile çalışanların oranı ise \% 6'dır. Çalışma nedenleri 6-14 yaş grubunda öncelik olarak "hane halkının ekonomik faaliyetine yardımcı olmak" amacını taşırken, 15-17 yaş gruplarında öncelikli olarak "hane halkı gelirine katkıda bulunma" ilk sırada yer almaktadır. "Ailenin isteği ile" ve "hane halkının ekonomik faaliyetine yardımcı olmak" nedeniyle çalışmak zorunda kalan çocukların 6-14 yaş grubunda daha yüksek olduğu görülmektedir.

Tablo 3. Milli Gelir Seviyesine Göre Çocuk İşçi Dağılımı- 5-17 Yaş Grubu, 2012

\begin{tabular}{lccc}
\hline $\begin{array}{l}\text { Milli Gelir } \\
\text { Kategorisi }\end{array}$ & $\begin{array}{c}\text { Toplam Çocuk } \\
\text { ('000) }\end{array}$ & $\begin{array}{c}\text { Çocuk İşçi } \\
\text { ('000) }\end{array}$ & $\begin{array}{c}\text { Çocuk } \\
\text { İş̧i } \\
\%\end{array}$ \\
\hline Düşük Gelir & 330,257 & 74,394 & 22.5 \\
Orta Alt Gelirli & 902,174 & 81,306 & 9.0 \\
Orta Üst Gelirli & 197,977 & 12,256 & 6.2 \\
\hline Ka
\end{tabular}

Kaynak: Efe ve Uluoğlu (2015)

Tablo 3 'ten de görüldüğü üzere milli gelir seviyesi düşük olan ülkelerde çocuk işçi oranı yükselmektedir. Düşük milli gelir seviyesi olan ülkelerde 2012 rakamlarına göre çocuk işçi oranı \% 22,5 iken orta gelirli ülkelerde \% 9'dur. Ortanın üstünde gelire sahip olan ülkelerde ise çocuk işçi oranı \% 6,2'dir.

Dolayısıyla çocukların çalışma hayatında görülmelerinin başlıca nedenleri arasında yoksulluğun geldiğini söyleyebiliriz. Bugün gerek ülkemizde gerekse diğer ülkelerde çocuk işçiliğinin gelişmemiş ve gelişmekte olan ülkelerde yoğun bir biçimde görülmesi de bu hipotezi doğrulamaktadır. Yoksulluk devam ettiği sürece de çocuk işçiliğinin tamamen yok edilemeyeceği görülmektedir (Avşar ve Öğ̈̈toğulları, 2012: 10).

Öte yandan çocukların özellikleri itibariyle yetişkinlere oranla çok düşük ücret karşılığı çalıștırıldıkları görülmektedir. Dolayısıyla çocuk işçiliği, yoksulluğun önlenmesi konusunda önemli bir etki taşımamaktadır. Bazı yaklaşımlar yoksulluk ve çocuk işgücü arasında doğrusal bir ilişki bulunduğunu, yoksulluğun çocuk istihdamına yol açtığını bazıları ise bu ilişkinin çocuk emeği ile başladığını düşünmektedir (Tunçcan, 2000: 244). Sosyal hakları oluşmamış, eğitim düzeyleri düşük ve yaşam standartları alt seviyede olan insanlar yaşamlarını sürdürebilmek için tüm aile bireylerini ekonomiye dâhil etmek zorunda kalmışlardır (Küçükkalay, 2000: 103-104).

\section{Dünyada ve Türkiye'de Çocuk Nüfusu}

2016 y1lında dünya nüfusunun \%30,3'ünü çocuk nüfus oluşturmaktadır. En yüksek çocuk nüfus oranına sahip ilk üç ülke sirasıyla; \%56 ile Nijer, \%55,3 ile Uganda ve \%54 ile Mali olmuştur. Türkiye \%28,7 ile 167 ülke arasında en fazla çocuk nüfus oranına sahip 96. ülke olmuştur (TÜİK, 2017).

2010 yılında Avrupa Birliği'ne üye olan ülkelerde çocukların toplam nüfus içerisindeki oranı \% 19 iken Türkiye'de bu 
oran \% 30,8'dir. Avrupa Birliği üyesi olan ülkelerde Fransa $\%$ 22,2 ile en yüksek çocuk nüfus üyesi oranına sahip ülke olmuştur. En düşük çocuk nüfus oranına sahip ülke ise \% 16,5 ile Almanya'dır (TÜİK, 2013). 2013 yilında çocuk nüfusun toplam nüfus içindeki oranı Avrupa Birliği üyesi ülkelerle karşılaştırıldığında \% 29,7 ile Türkiye en yüksek ülke olmuştur. Almanya \% 16 ile yine en düşük çocuk nüfusuna sahip ülke olmuştur. Çocuk nüfus oranı Fransa'da $\% 22,2$, İngiltere'de \%21,2, İsveç'te \%20,2, Yunanistan'da $\% 17,6$ ve İtalya'da \%16,8'dir (TÜİK, 2014).

Tablo 4. Cocuk Nüfus ve Oranı 1935-2016

\begin{tabular}{cccc}
\hline Y11 & Toplam Nüfus & $\begin{array}{c}\text { Toplam Çocuk } \\
\text { Nüfus } \\
(0-17 \text { Yaş) }\end{array}$ & $\begin{array}{c}\text { Çocuk Nüfusun } \\
\text { Toplam } \\
\text { Nüfus İçindeki Oranı }\end{array}$ \\
\hline 1935 & 16158018 & 7277722 & 45,0 \\
1945 & 18790174 & 8667314 & 46,1 \\
1950 & 20947188 & 9470412 & 45,2 \\
1955 & 24064763 & 10902635 & 45,3 \\
1960 & 27754820 & 12823514 & 46,2 \\
1965 & 31391421 & 14998754 & 47,8 \\
1970 & 35605176 & 17263147 & 48,5 \\
1975 & 40347719 & 18969445 & 47,0 \\
1980 & 44736957 & 20572272 & 46,0 \\
1985 & 50664458 & 22360927 & 44,1 \\
1990 & 56473035 & 23577783 & 41,8 \\
2000 & 64729501 & 22800988 & 35,2 \\
2007 & 70586256 & 22298628 & 31,6 \\
2008 & 71517100 & 22497241 & 31,5 \\
2009 & 72561312 & 22638411 & 31,2 \\
2010 & 73722988 & 22699503 & 30,8 \\
2011 & 74724269 & 22709283 & 30,4 \\
2012 & 75627384 & 22692174 & 30,0 \\
2013 & 76667864 & 22761702 & 29,7 \\
2014 & 77695904 & 22838482 & 29,4 \\
2015 & 78741053 & 22870683 & 29,0 \\
2016 & 79814871 & 22891140 & 28,7 \\
\hline
\end{tabular}

Kaynak: TÜİK (2016)

Türkiye nüfusu 2012 yılı sonu itibariyle 75 milyon 627 bin 384, 2013 yılı sonu itibariyle 76 milyon 667 bin 864, 2014 yılı sonu itibariyle 77 milyon 695 bin 904, 2015 yılı sonu itibariyle 78 milyon 741 bin 053, 2016 yılı sonu itibariyle 79 milyon 814 bin 871 olmuştur. 0-17 yaş grubunu içeren çocuk nüfus, 2012 y1lında toplam nüfusun \% 30'unu, 2013 y1lında \% 29,7'sini, 2014 yılında \% 29,4'ünü, 2015 yılında \% 29'unu, 2016 yılında \% 28,7'sini oluşturmaktadır.

Şekil 2. Çocuk Nüfusun Toplam Nüfus İçindeki Oranı 1935-2075

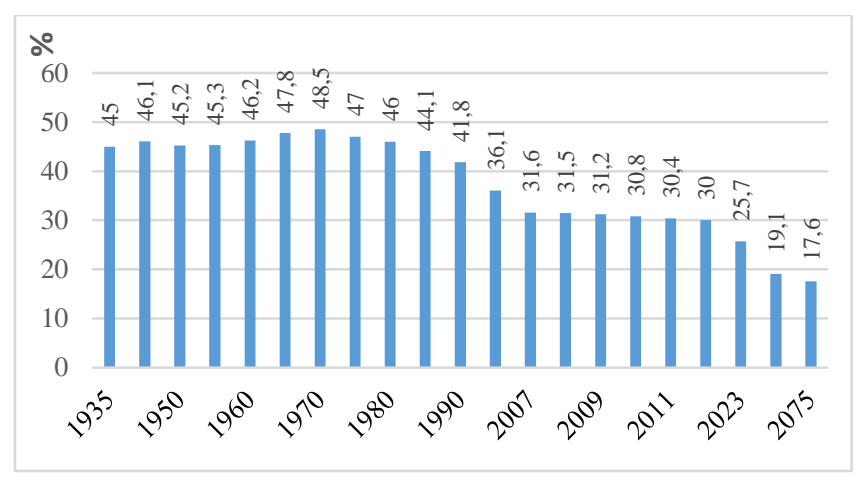

Kaynak: TÜIKK (2012)

Şekil 2'ye baktığımızda ülkemizdeki çocuk nüfus oranının 2023 yilında \%25,7, 2050 yilında \%19,1 ve 2075 yilında \%17,6’ya düşeceği öngörülmektedir.

\section{Dünyada ve Türkiye'de Çocuk İşçiliği}

\subsection{Türkiye'de Çocuk İşçiliği}

Türkiye'de çocuklar ve gençler Anayasamızca korunmaktadırlar. Anayasamızda hiç kimsenin yaşına, cinsiyetine, gücüne uygun olmayan işlerde çalıştırılamayacağı ve çalışma şartları açısından küçüklerin özel olarak korunması gerekliliği hüküm altına alınmıştır (ASPB, 2013: 22).

4857 sayılı İş Kanunu'nun 71. maddesine dayanılarak çıkarılan Çocuk ve Genç İşçilerin Çalıştırılma Usul ve Esasları Hakkında Yönetmeliğin 4. maddesinde çocuk işçi, "14 yaşını bitirmiş, 15 yaşını doldurmamış ve ilköğretimini tamamlamış kişi, genç işçi de 15 yaşını tamamlamış, ancak 18 yaşını tamamlamamış” kişi olarak tanımlanmaktadır.

Tablo 5. Türkiye'de Yaş Grubu ve Cinsiyete Göre Kurumsal Olmayan Sivil Nüfus* ve İstihdam 2006-2012 (Ekim-KasımAralık)

\begin{tabular}{|c|c|c|c|c|c|c|}
\hline \multirow{2}{*}{$\begin{array}{l}\text { Yaş } \\
\text { grubu } \\
\text { ve } \\
\text { cinsiyet }\end{array}$} & \multicolumn{2}{|c|}{$\begin{array}{l}\text { Kurumsal olmayan nüfus } \\
\text { (bin kişi) }\end{array}$} & \multicolumn{2}{|c|}{$\begin{array}{l}\text { İstihdam } \\
\text { edilenler } \\
\text { (bin kişi) }\end{array}$} & \multicolumn{2}{|c|}{$\begin{array}{l}\text { İstihdam } \\
\text { oran1 } \\
(\%)\end{array}$} \\
\hline & 2006 & 2012 & 2006 & 2012 & 2006 & 2012 \\
\hline Toplam & 68378 & 73950 & 20980 & 25584 & 34,5 & 38,5 \\
\hline $0-5$ & 7519 & 7481 & - & - & - & - \\
\hline $6-17$ & 15025 & 15247 & 890 & 893 & 5,9 & 5,9 \\
\hline 6- 14 & 11378 & 11386 & 285 & 292 & 2,5 & 2,6 \\
\hline $15-17$ & 3647 & 3861 & 605 & 601 & 16,6 & 15,6 \\
\hline $18-24$ & 7987 & 7734 & 2990 & 3073 & 37,4 & 39,7 \\
\hline $25-34$ & 11680 & 12683 & 6485 & 7688 & 55,5 & 60,6 \\
\hline $35-54$ & 16935 & 19488 & 8839 & 11337 & 52,2 & 58,2 \\
\hline $55+$ & 9231 & 11317 & 1776 & 2593 & 19,2 & 22,9 \\
\hline Erkek & 33914 & 36760 & 15603 & 18009 & 51,9 & 54,7 \\
\hline $0-5$ & 3853 & 3834 & - & - & - & - \\
\hline $6-17$ & 7677 & 7775 & 601 & 614 & 7,8 & 7,9 \\
\hline $6-14$ & 5809 & 5794 & 190 & 185 & 3,3 & 3,2 \\
\hline $15-17$ & 1868 & 1981 & 411 & 430 & 22,0 & 21,7 \\
\hline $18-24$ & 3801 & 3762 & 2009 & 2019 & 52,9 & 53,7 \\
\hline $25-34$ & 5845 & 6363 & 4935 & 5448 & 84,4 & 85,6 \\
\hline $35-54$ & 8505 & 9775 & 6748 & 8068 & 79,3 & 82,5 \\
\hline $55+$ & 4233 & 5251 & 1310 & 1860 & 30,9 & 35,4 \\
\hline Kadın & 34464 & 37189 & 5377 & 7576 & 17,5 & 22,6 \\
\hline $0-5$ & 3666 & 3648 & - & - & - & - \\
\hline $6-17$ & 7349 & 7472 & 289 & 279 & 3,9 & 3,7 \\
\hline 6- 14 & 5569 & 5592 & 95 & 108 & 1,7 & 1,9 \\
\hline $15-17$ & 1780 & 1880 & 194 & 171 & 10,9 & 9,1 \\
\hline $18-24$ & 4186 & 3972 & 981 & 1054 & 23,4 & 26,5 \\
\hline $25-34$ & 5836 & 6320 & 1550 & 2240 & 26,6 & 35,4 \\
\hline $35-54$ & 8430 & 9713 & 2091 & 3270 & 24,8 & 33,7 \\
\hline $55+$ & 4998 & 6065 & 466 & 733 & 9,3 & 12,1 \\
\hline $35-54$ & 8505 & 9775 & 6748 & 8068 & 79,3 & 82,5 \\
\hline $55+$ & 4233 & 5251 & 1310 & 1860 & 30,9 & 35,4 \\
\hline
\end{tabular}

* Kurumsal Olmayan Sivil Nüfus: Üniversite yurtları, yetiștirme yurtları (yetimhane), huzurevi, özel nitelikteki hastahane, hapishane, kışla vb. yerlerde ikamet edenler dışında kalan nüfustur. Kaynak: TÜİK (2012)

2006 yılı çocuk işgücü anketi sonuçlarına göre, 6-17 yaş grubundan 16 milyon 264 bin çocuktan \%5,9'u ekonomik bir işte çalışmaktadır. 2012 yılı çocuk işgücü anketi sonuçlarına göre ise aynı yaş grubundan 15 milyon 247 bin çocuktan ekonomik işlerde çalışanların sayısı 2006 yılına kıyasla artarken, oran \%5,9 olarak aynı kalmıştır. 6-14 yaş grubunda 
ise 2012 yılında, 2006 verilerine göre hem istihdam edilen çocuk sayısı artmıştır hem de istihdam oranı \%2,5'ten \%2,6'ya çıkmıştır.

Tablo 6. Yerleşim Yeri, Yaş Grubu, Cinsiyet ve Çalışma Durumuna Göre Çocuk Sayısı ve Oranı, 2012

\begin{tabular}{|c|c|c|c|c|c|c|c|c|c|}
\hline & \multicolumn{3}{|c|}{$\begin{array}{c}\text { Toplam } \\
\text { çocuk sayısı }\end{array}$} & \multicolumn{2}{|c|}{$\begin{array}{l}\text { Ekonomik } \\
\text { işlerde } \\
\text { çalışanlar }\end{array}$} & \multicolumn{2}{|c|}{$\begin{array}{l}\text { Ev işlerinde } \\
\text { faaliyette } \\
\text { bulunan }\end{array}$} & \multicolumn{2}{|c|}{ Çalışmayan } \\
\hline & & Say1 & $\%$ & Sayı & $\%$ & Say1 & $\%$ & Say1 & $\%$ \\
\hline \multicolumn{10}{|c|}{ Türkiye } \\
\hline Toplam & $\mathrm{T}$ & 15247 & 100 & 893 & 5,9 & 7503 & 49,2 & 6850 & 44,9 \\
\hline & E & 7775 & 100 & 614 & 7,9 & 3243 & 41,7 & 3917 & 50,4 \\
\hline & $\mathrm{K}$ & 7472 & 100 & 279 & 3,7 & 4261 & 57,0 & 2933 & 39,3 \\
\hline \multirow{3}{*}{ 6-14 } & $\mathrm{T}$ & 11386 & 100 & 292 & 2,6 & 5290 & 46,5 & 5804 & 51,0 \\
\hline & $\mathrm{E}$ & 5794 & 100 & 185 & 3,2 & 2401 & 41,4 & 3208 & 55,4 \\
\hline & K & 5592 & 100 & 108 & 1,9 & 2889 & 51,7 & 2596 & 46,4 \\
\hline \multirow[t]{3}{*}{$15-17$} & $\mathrm{~T}$ & 3861 & 100 & 601 & 15,6 & 2213 & 57,3 & 1047 & 27,1 \\
\hline & $\mathrm{E}$ & 1981 & 100 & 430 & 21,7 & 842 & 42,5 & 710 & 35,8 \\
\hline & $\mathrm{K}$ & 1880 & 100 & 171 & 9,1 & 1372 & 73,0 & 337 & 17,9 \\
\hline \multicolumn{10}{|c|}{ Kent } \\
\hline \multirow[t]{3}{*}{ Toplam } & & 10139 & 100 & 400 & 3,9 & 5479 & 54,0 & 4259 & $\overline{42,0}$ \\
\hline & E & 5157 & 100 & 302 & 5,9 & 2460 & 47,7 & 2395 & 46,4 \\
\hline & K & 4982 & 100 & 98 & 2,0 & 3020 & 60,6 & 1864 & 37,4 \\
\hline \multirow[t]{3}{*}{$6-14$} & $\mathrm{~T}$ & 7567 & 100 & 79 & 1,0 & 3888 & 51,4 & 3600 & 47,6 \\
\hline & E & 3845 & 100 & 57 & 1,5 & 1829 & 47,6 & 1960 & 51,0 \\
\hline & K & 3722 & 100 & 22 & 0,6 & 2059 & 55,3 & 1640 & 44,1 \\
\hline \multirow[t]{3}{*}{$15-17$} & $\mathrm{~T}$ & 2572 & 100 & 322 & 12,5 & 1591 & 61,9 & 659 & 25,6 \\
\hline & $\mathrm{E}$ & 1312 & 100 & 246 & 18,8 & 631 & 48,1 & 436 & 33,2 \\
\hline & $\mathrm{K}$ & 1260 & 100 & 76 & 6,0 & 960 & 76,2 & 224 & 17,8 \\
\hline \multicolumn{10}{|c|}{ Kir } \\
\hline \multirow{3}{*}{ Toplam } & $\mathrm{T}$ & 5108 & 100 & 493 & 9,7 & 2024 & 39,6 & 2591 & 50,7 \\
\hline & E & 2618 & 100 & 312 & 11,9 & 783 & 29,9 & 1523 & 58,2 \\
\hline & $\mathrm{K}$ & 2491 & 100 & 181 & 7,3 & 1241 & 49,8 & 1069 & 42,9 \\
\hline \multirow[t]{3}{*}{$6-14$} & $\mathrm{~T}$ & 3819 & 100 & 214 & 5,6 & 1402 & 36,7 & 2203 & 57,7 \\
\hline & $\mathrm{E}$ & 1948 & 100 & 128 & 6,6 & 572 & 29,4 & 1249 & 64,1 \\
\hline & $\mathrm{K}$ & 1870 & 100 & 86 & 4,6 & 830 & 44,4 & 955 & 51,1 \\
\hline \multirow[t]{3}{*}{$15-17$} & $\mathrm{~T}$ & 1290 & 100 & 279 & 21,6 & 622 & 48,2 & 388 & 30,1 \\
\hline & $\mathrm{E}$ & 669 & 100 & 184 & 27,5 & 211 & 31,5 & 274 & 41,0 \\
\hline & $\mathrm{K}$ & 620 & 100 & 95 & 15,3 & 411 & 66,3 & 114 & 18,4 \\
\hline
\end{tabular}

* T: Toplam; E: Erkek; K: Kadın

Kaynak: TÜİK (2012)

2012 yılında 6-17 yaș aralığındaki çocuk nüfusun (15 milyon 247 bin) \% 5,9'u (893 bin) ekonomik işlerde istihdam edilmektedir. Çocukların \% 49,2'si ev işlerinde faaliyette bulunurken, \% 44,9'u çalışmamaktadır. İstihdam oranı, 6-14 yaş grubunda \%2,6, 292 bin $15-17$ yaş grubunda $\% 15,6,601$ bindir.

Kırda çalışan çocuk sayısı ise kenttekine göre daha fazladır. Kentte 400 bin kişi yani \% 3,9'u ekonomik işlerde çalışırken kırda 493 bin kişi, \% 9,7'si ekonomik işlerde çalışmaktadır.

Çocukların \% 91,5'i bir okula devam ederken, \% 8,5'i okula devam etmemektedir (TÜİK, 2013). Bilindiği gibi 6-14 yaş grubu arasındaki çocukların çalıştırılması kanunen yasaktır. Ancak bu yaş grubunda çalıştırılan 292 bin çocuğun yaklaşık \% 20'sinin zorunlu eğitimi terk ettiği, 15-17 yaş grubundaki çalışan çocukların ise yaklaşık \% 66'sının orta öğrenime devam etmediği görülmektedir (ASPB, 2013: 22).

2012 yılında \% 54,2 hane halkında 0-17 yaş grubuna dâhil en az bir çocuk bulunmaktadır (TÜİK, 2013). Bu oran 2013 yılında \% 53,2'dir. 2013 yılında hane halklarının $\% 39,7$ 'sinde bir çocuk, \%35,5'inde iki çocuk, \%14,5'inde üç çocuk, $\% 5,3$ 'ünde dört çocuk ve $\% 5$ 'inde beş ve daha fazla çocuk bulunduğu görülmüştür (TÜİK, 2014).
Şekil 3. Yaş Grubu, Cinsiyet ve Sektöre Göre Ekonomik Faaliyetlerde Çalışan Çocuklar 2006 - 2012

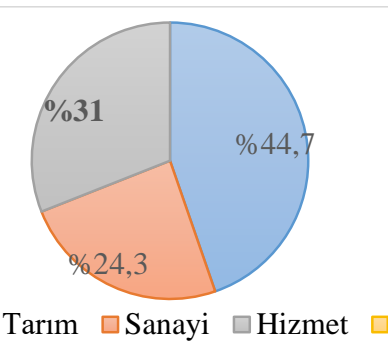

Kaynak: TÜİK (2012)

Türkiye İstatistik Kurumu'nun uyguladığı “Çocuk İşgücü Anketi” sonuçlarına göre çalışan çocukların 399 bin kişisi \% 44,7'si tarım sektöründe çalıșmaktadır. 277 bin kiși \% 31 'i hizmet sektöründe çalışırken, 217 bin kişi \%24,3'ü sanayi sektöründe çalışmaktadır. Sektör bazlı sonuçları 2006 yılı ile karşılaştırdığımızda tarım sektöründe çalışanların payı \% 8,1 artmıştır. Hizmet sektörünün payı \% 1,5, sanayi sektörünün payı ise \% 6,6 azalmıştır. Çocukların 470 bin kişisi \% 52,6'sı ücretli ve yevmiyeli olarak yüzde 46,22si 413 bini ise ücretsiz aile işçisi olarak çalışmaktadır.

Tablo 7. Haftalık Fiili Çalışma Süresine Göre Ekonomik Faaliyetlerde Çalışan Çocuklar, 2006

\begin{tabular}{|c|c|c|c|}
\hline \multicolumn{4}{|c|}{ Türkiye } \\
\hline & Toplam & Erkek & Kadın \\
\hline Toplam & 100 & 100 & 100 \\
\hline 1.Tem & 7.5 & 6.6 & 9.2 \\
\hline Ağu. 15 & 11.1 & 10.8 & 11.7 \\
\hline $16-30$ & 17.5 & 16.8 & 18.7 \\
\hline $31-39$ & 5.3 & 5.7 & 4.6 \\
\hline $40-45$ & 6.9 & 5.9 & 8.9 \\
\hline $46-54$ & 13.6 & 14.4 & 12 \\
\hline $55+$ & 36 & 37.7 & 33.1 \\
\hline İşbaşında olmayanlar & 2.1 & 2.2 & 2.1 \\
\hline $40+$ & 56.25 & 57.9 & 54 \\
\hline \multicolumn{4}{|c|}{ Kent } \\
\hline & Toplam & Erkek & Kadın \\
\hline Toplam & 100 & 100 & 100 \\
\hline 1.Tem & 4.2 & 4.2 & 4.2 \\
\hline Ağu.15 & 6.3 & 7.1 & 4.2 \\
\hline $16-30$ & 13.3 & 13.6 & 13.3 \\
\hline $31-39$ & 3.9 & 4.2 & 2.5 \\
\hline $40-45$ & 6.8 & 5.3 & 10.8 \\
\hline $46-54$ & 19.5 & 18.4 & 22.5 \\
\hline $55+$ & 44.4 & 45.7 & 40.8 \\
\hline İşbaşında olmayanlar & 1.5 & 1.5 & 1.7 \\
\hline $40+$ & 70.7 & 69.4 & 74.2 \\
\hline \multicolumn{4}{|c|}{ Kir } \\
\hline & Toplam & Erkek & Kadın \\
\hline Toplam & 100 & 100 & 100 \\
\hline 1.Tem & 10.6 & 9.5 & 12.1 \\
\hline Ağu. 15 & 15.4 & 14.9 & 16 \\
\hline $16-30$ & 21.2 & 20.7 & 22.3 \\
\hline $31-39$ & 6.6 & 7.1 & 5.8 \\
\hline $40-45$ & 7 & 6.4 & 7.8 \\
\hline $46-54$ & 8.2 & 9.8 & 5.8 \\
\hline $55+$ & 28.5 & 28.5 & $28 .+$ \\
\hline İşbaşında olmayanlar & 2.8 & 3.1 & 2.4 \\
\hline $40+$ & 43.7 & 44.7 & 42.2 \\
\hline
\end{tabular}

Kaynak: TÜİK (2006)

6-17 yaş aralığındaki erkek çocukların \% 57,9'u kız çocuklarının ise \% 54'ü haftada 40 saatten fazla çalışmaktadır. 40 saat ve üzeri çalışan çocukların oranı kent kırsal alana göre daha yüksektir. 


\subsection{Dünyada Çocuk İşçiliği}

Çocuk işçiliği yıllara göre azalsa da toplumsal bir sorun olarak halen devam etmektedir. Tablo 9'da görüldüğü gibi Dünyada 2012 yılında 168 milyon çocuk iş̧̧i çalışmaktadır. $\mathrm{Bu}$ çocukların yarısından fazlası (85 milyonu) tehlikeli işlerde çalışmaktadır. Bu da dünya nüfusunun $\%$ 5,4'ünü oluşturmaktadır.

Tablo 8. Dünyada Yillar İtibariyle Çocuk İşçiliği, 5-17 yaş, 20002012

\begin{tabular}{|c|c|c|c|c|}
\hline & $\begin{array}{c}\text { Çocuk } \\
\text { İşçiliği } \\
\text { (Bin) }\end{array}$ & $\begin{array}{l}\text { Çocuk } \\
\text { İşçiliği } \\
(\%)\end{array}$ & $\begin{array}{c}\text { En Kötü } \\
\text { Biçimlerde } \\
\text { Çocuk İşçiliği } \\
\text { (Bin) }\end{array}$ & $\begin{array}{c}\text { En Kötü } \\
\text { Biçimlerde } \\
\text { Çocuk İşçiliği } \\
(\%)\end{array}$ \\
\hline 2000 & 245.500 & 16,0 & 170.500 & 11,1 \\
\hline 2004 & 222.294 & 14,2 & 128.381 & 8,2 \\
\hline 2008 & 215.209 & 13,6 & 115.314 & 7,3 \\
\hline 2012 & 167.956 & 10,6 & 85.344 & 5,4 \\
\hline
\end{tabular}

Kaynak: ÇSGB (2017)

Tablo 9. Çocuk İşçiliğinin Bölgesel Dağılımı, 5-17 yaş, 2012

\begin{tabular}{|c|c|c|c|c|c|}
\hline Bölge & $\begin{array}{l}\text { Çocuk } \\
\text { Nüfusu }\end{array}$ & $\begin{array}{l}\text { Cocuk } \\
\text { İşçiliği } \\
\text { (Bin) }\end{array}$ & $\begin{array}{l}\text { Çocuk } \\
\text { İşçiliği } \\
(\%)\end{array}$ & $\begin{array}{c}\text { En Kötü } \\
\text { Biçimlerde } \\
\text { Çocuk İşçiliği } \\
\text { (bin) }\end{array}$ & $\begin{array}{c}\text { En Kötü } \\
\text { Biçimlerde } \\
\text { Çocuk işçiliği } \\
(\%)\end{array}$ \\
\hline $\begin{array}{l}\text { Asya ve } \\
\text { Pasifik }\end{array}$ & 835.334 & 77.723 & 9,3 & 33.860 & 4,1 \\
\hline $\begin{array}{l}\text { Sahra } \\
\text { Güneyi } \\
\text { Afrika }\end{array}$ & 275.397 & 59.031 & 21,4 & 28.767 & 10,4 \\
\hline $\begin{array}{c}\text { Latin } \\
\text { Amerika ve } \\
\text { Karayipler }\end{array}$ & 142.693 & 12.505 & 8,8 & 9.638 & 6,8 \\
\hline
\end{tabular}

2012 rakamlarına baktığımızda çocuk iş̧̧iliğinin en fazla Asya ve Pasifik ülkelerinde olduğu görülmektedir. Bu bölgede 77 bin 723 çocuk işçi bulunmaktadır. Yüzde olarak 9,3'e denk gelmektedir. Bu çocukların 33 bin 860'1 \% 4,1'i kötü şartlarda çalışmaktadır. Sahra Güneyi Afrika bölgesinde 275 milyon 397 bin çocuğun \% 21,4'ü bir başka deyişle 59 bin 31 'i çocuk işçidir. Kötü biçimde çalışan çocuk işçileri en fazla Sahra Güneyi Afrika bölgesindedir (\% 10,4). Latin Amerika ve Karayipler'de ise 142 bin 693 çocuğun \% $8,8^{\prime}$ i çocuk iş̧̧idir.

Alliance göre 2017 yılında dünyada 5-17 yaş aralı̆̆ındaki çocuk iş̧̧i sayısı 151,6 milyondur. Bu kişilerden neredeyse yarısı 72,5 milyonu ise tehlikeli işlerde çalışmaktadırlar.

Şekil 4. Çocuk Emeğinin Global Olarak Değerlendirilmesi (2017)

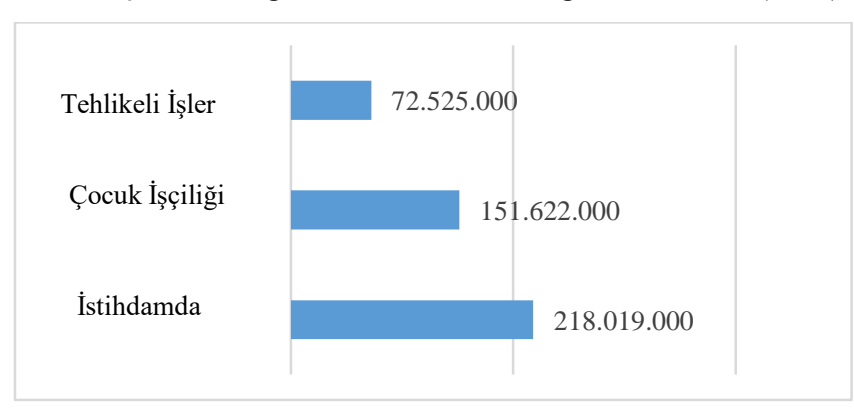

Kaynak: Alliance (2017)
Şekil 5. Yaş Gruplarına Göre Tehlikeli İşlerde Çalışan Çocuklar (2017)

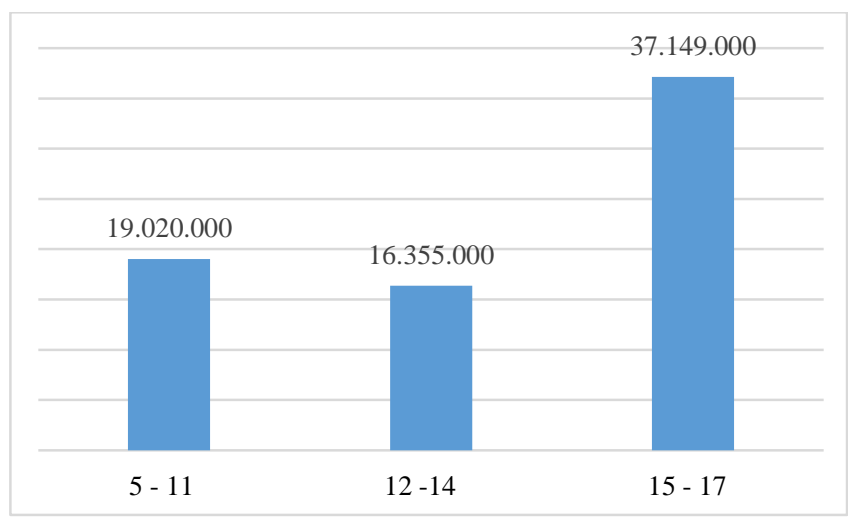

Kaynak: Alliance (2017)

15-17 yaş grubundaki kişiler tehlikeli işlerde çalışan grubun çoğunluğunu oluşturmaktadır (37 milyon 149 bin). Bunu sırasılyla 16 milyon 355 bin kişi ile 12-14 yaş grubu aralığındaki kişiler, 19 milyon ile 5-11 yaş aralığındaki kişiler oluşturmaktadır.

Şekil 6. Çocuk İşçiliğindeki Yaş Gruplarına Göre Eğilim (2017)

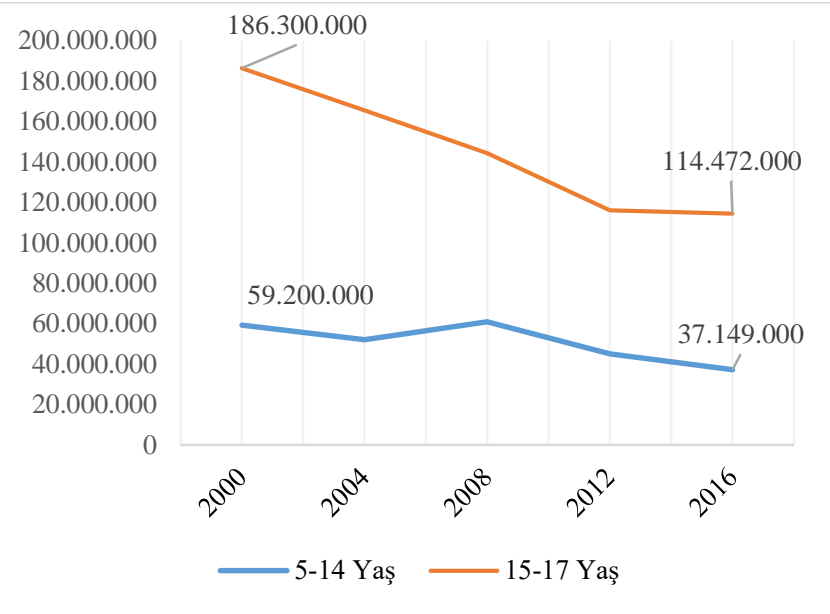

Kaynak: Alliance (2017)

Çocuk işçiliğinin yaş gruplarına göre eğilimine baktığımızda 5-14 yaş grubu aralığındaki çocukların 2000'li yıllardan 2016'ya gelindiğinde düşme eğiliminde olduğu görülmektedir.

Şekil 7. Cinsiyete Göre Çalışma Sayıları (2017)

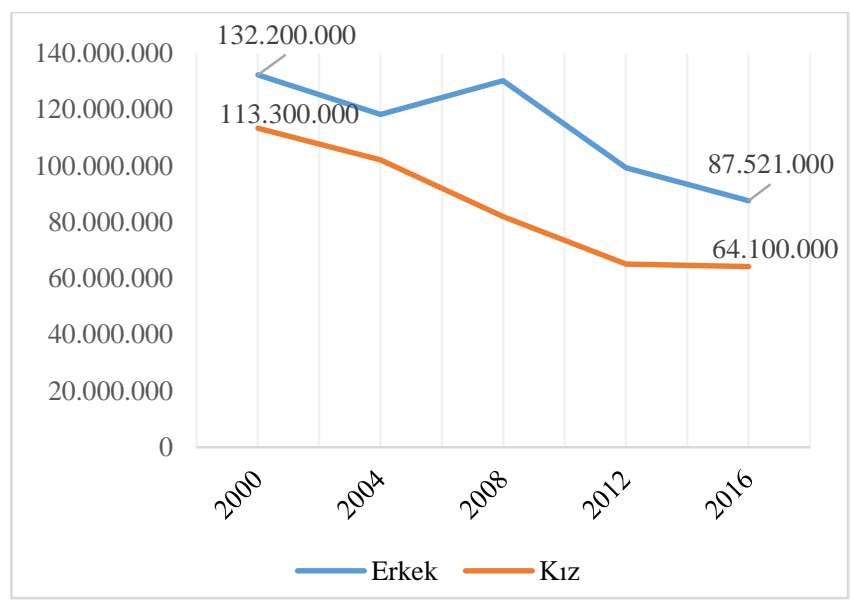

Kaynak: Alliance (2017) 
Cinsiyete göre çocuk işçiliğine baktığımızda 2000 yılında erkeklerde 132,200 kızlarda 113,200 olup birbirine yaklaşık değerlerdir. 2016 yılına gelindiğinde ise farkın kızlar lehine açılmış olduğu görülmektedir.

Şekil 8. Bölgelere Göre Çocuk İş̧̧iliği (2017)

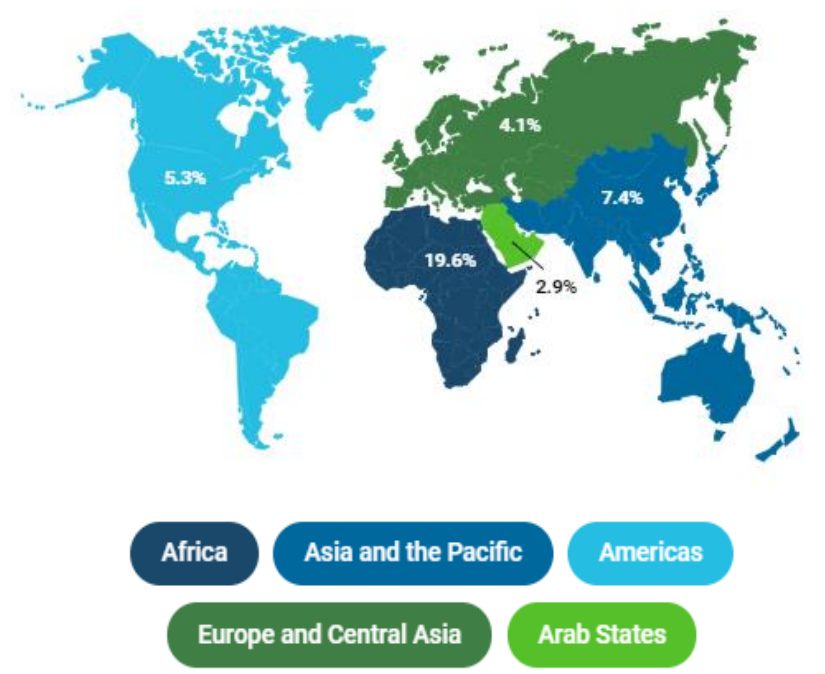

Kaynak: Alliance (2017)

Çocuk işçiliği \% 19,6 ile en fazla Afrika'da görülmektedir. Afrika'da her beş çocuktan biri çalışmaktadır. Afrika'yı \% 7,4 ile Asya ve Pasifik izlemektedir.

Çocuk işgücü az gelişmiş ülkelerde varlığını daha çok hissettirse de Ortadoğu, Asya, Afrika, Latin Amerika'da bulunan gelişmekte olan ülkelerde de yoğun bir şekilde görülmektedir (Küçükkalay vd., 2000: 105). Kentsel bölgelerde yaşamını sürdüren çocuklar sanayi ve hizmet ağırlıklı iş kollarında çalışmaktadırlar. Ev işleri, çocuk bakıcılığı, dükkân, atölye, restoranları örnek olarak verebiliriz. Kırsal kesimlerde ise çocuklar ev işleri, tarım ve hayvancılık sektöründe çalışmaktadırlar. Az gelişmiş ülkelerde emek yoğun teknoloji ile üretim yapıldığından daha düşük ücretlerle çalışacak, daha kolay işten çıkarılabilecek, örgütsüz olan çocuk işçiler, işverenlerce daha çok tercih edilmektedir. (Efe ve Uluoğlu, 2015: 47).

Şekil 9. Yaş Gruplarına ve Ekonomik Sektörlere Göre Çocuk İşçiliği Dağılımı (2017)

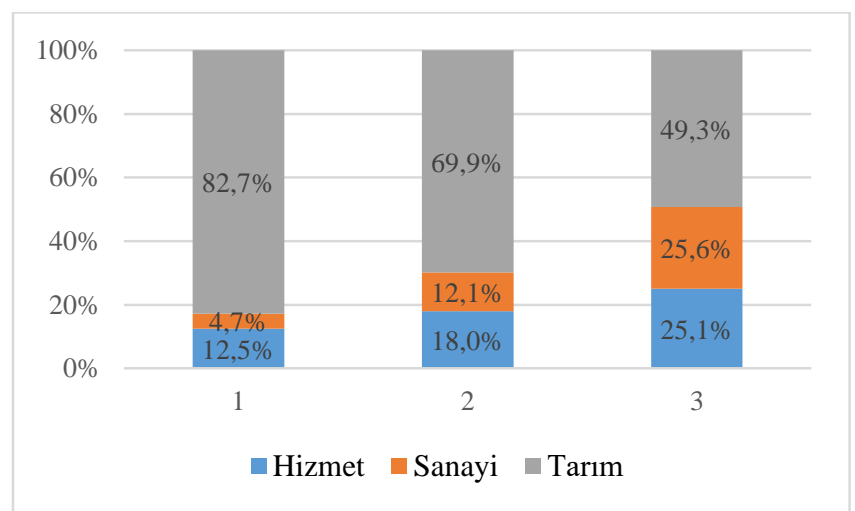

Kaynak: Alliance (2017)

Çocuk işçiliğinde on çocuktan yedisi tarımda çalışmaktadır. 5-11 yaş aralığında \% 82,7, 12-14 yaş aralığında \% 69,9, 15 17 arasında $\% 49,3$ çocuk tarımda çalışmaktadır.

\section{5. Çocuk İşçiliği İle Uluslararası ve Ulusal Mücadele Biçimleri}

Çocuk işçiliği problemi çözümsüz bir problem değildir. Ancak problemin büyüklüğü, bir anda ve bireysel çözüme kavuşturulmasını da imkânsız kılmaktadır. Bunun için çocuk işçiliği problemi, hem zamana yayılmış bir plan dâhilinde, hem de ulusal ve uluslararası düzeyde soruna doğrudan ve dolaylı olarak tarafların işbirliğiyle çözümlenmelidir.

\subsection{Uluslararası Mücadele}

\subsubsection{Sosyal Anlaşma (Social Clause)}

Çocuk işçiliği uluslararası ticarette büyük boyutlarda yer almasına karşın, iki önemli ticaret anlaşması olan GATT (General Agreement on Tariff and Trade) ve Uruguay Round' da çocuk işçiliğine ilişkin hüküm bulunmamaktadır (Kamm, 1995: 10).

Uluslarası Çalışma Örgütü ile Dünya Ticaret Örgütü (World Trade Organization) arasında yapılacak anlaşma, tüm ticari haklardan faydalandığı halde çocuk işçiliği konusunda hiçbir harekette bulunmayan ülkeleri, çocuk istihdamını önlemeye adım atmaya yöneltebilir. Bu iki uluslararası örgüt arasında yapılacak sosyal anlaşma, çocuk işçiliği yanında, çalışma hayatı ile ilgili diğer alanları da (temel sendikal haklar, her türlü ayrımcılık ve zorunlu çalışma) kapsama alabilir (ICFTU, 1996: 5).

Gelişmiş ülkelerde kamuoyu, bu iki örgütü böyle bir anlaşma yapmaya itmektedir. Çünkü gelişmiş ülkelerdeki pek çok kuruluş, tüketiciler ve üreticiler; başta çocuk hakları olmak üzere insan haklarına saygı gösterilmesini istemektedirler. Örneğin, Lewis Strauss, Reebok ve Sears gibi sportif mal imal eden firmalar, kendi bünyeleri yanında, taşeronlarınca üretilen mamullerin de hangi şartlarda üretildiğine bakmaktadırlar. Avrupa'da kurulmuş pek çok mağaza da, üzerinde çocuk işçilerce üretilmediğine dair etiket olamayan malları satmamaya karar vermiştir (ILO, 1996b: 6; Tucker, 1997: 11; Winner, 1996: 66).

Avrupa Birliği bu konuda Genel Tercihler Sistemi (Generalized System of Preferences) isimli bir anlaşma kabul etmiştir. Bu sistemde (ILO, 1996a: 24; ILO, 1996b: 6; World of Work, 1996a: 17) gelişmekte olan ülkelerden ithal edilen birçok ürüne karşı (gümrük ) tarifeleri azaltılırken, mahkûmlar ve köleler tarafından üretilen ürünlere sınır konulmakta, ILO sözleşmelerinde belirtilen şekliyle, çocuk işçi istihdam edilmemesine ve sendikal haklara saygı gösterilmesine dikkat edilmektedir. Bu şartlara uyan ülkelere AB pazarlarına girmede öncelik tanınmaktadır.

Yoğun bir biçimde çocuk istihdam edilen gelişmekte olan ülkelere ekonomik yaptırımlar içeren bu uluslararası araçların, çok dikkatli kullanılması gerekmektedir. Çünkü söz konusu ekonomik yaptırımlar, gelişmekte olan ülkelerde sadece ihraç ekonomilerini etkileyecektir. $\mathrm{Bu}$ da, bu sektörlerde çalışan çocukların, ülkedeki diğer (iç piyasaya mal üreten) sektörlere kaymasını doğuracaktır. ILO'nun deneyimlerinden, özellikle Asya ülkelerindeki ihraç sanayilerinde, böyle bir karara karşı çok sayıda işverenin derhal çocuk işçileri işten çıkardığı görülmüştür. $\mathrm{Bu}$ çocuklardan okula dönenlere ise hiç rastlanmamıştır. İşten çıkarılan çocuklar sadece iş (sektör) değiştirmiştir (ILO, 1996a:25). Bu örnek bize, çocuk işçiliğinde negatif 
güdülemenin (ekonomik yaptırım) her zaman istenilen amaçlara hizmet etmediğini açıkça göstermektedir.

\subsection{2. Çok Uluslu Şirketler}

Çocuk işçiliği ile mücadelede çok uluslu şirketlerin rolü çok önemlidir. Bu şirketler aracılığıyla, bu konuda daha az sürede daha fazla mesafe almak mümkündür.

Çok uluslu şirketler, üretimlerinin her aşamasında çocuk istihdam etmeme konusunda kendi içlerinde bir anlaşmaya varabilir veya bu şirketler üretimlerinin her aşamasında, yan kuruluşlarında, taşeronlarında temel insan haklarını ihlal etmeme konusunda tedbir almaya zorlanabilirler. Bu konuda çok uluslu şirketlerin davranışlarını düzenleyen uluslararası kurallara önemle ihtiyaç vardır.

Böyle bir düzenleme ile söz konusu şirketlerin ve onlara iş yapan taşeronlarının, çocuk haklarının ihlalini içerecek biçimlerde çocuk çalıştırmaması sağlanabilir.

Çok uluslu şirketler satım alma politikalarını da, çocukların yüksek yararını gözetecek biçimde geliştirebilir ve bu yararı koruyacak önlemleri alabilirler.

\subsubsection{Tüketiciler}

Dünyada her insan tüketici olarak, çocuk işçiliğine karş1 mücadele edebilir. Bunun bir yöntemi, çocuk işçiler tarafından üretilen ürünleri satın almamak şeklinde olabilir. Ayrıca tüketiciler bireysel olarak, çocuk işçiliği ile mücadele eden kuruluşların faaliyetlerinde görev alabilirler ve etkinliklerine destek verebilirler.

\subsubsection{Uluslararası Kuruluşların Faaliyetleri}

ILO çocuk işçiliğine karşı tüm tarafların harekete geçmesinde başat ve merkezi bir rol oynamaktadır. Ancak çocuk işçiliği ile mücadelede uluslararası düzeyde ILO'nun da tek başına başarılı olması mümkün değildir. ILO'nun faaliyetleri başta diğer Birleşmiş Milletler (BM) kuruluşları olmak üzere diğer uluslararası kuruluşlarca da desteklenmelidir.

Bu konuda BM İnsan Hakları Komitesi'ne, özellikle tehlikeli işlerde çalışan çocukların sağlığı ile ilgili olarak Dünya Sağlık Örgütü'ne (WHO), çocukların çalışması, okula katılmalarını ve devamlarını engellediği için Birleşmiş Milletler Eğitim Bilim ve Kültür Örgütü'ne (UNESCO), özellikle zor şartlar altında çalışan çocuklar açısından Birleşmiş Milletler Uluslararası Çocuklara Acil Yardım Fonu'na (UNICEF), aile planlaması ve genç eğitim programları ile çocuk işçiliğinin sona erdirilmesine katkıda bulunması açısından Birleşmiş Milletler Nüfus Fonu'na (Suteliffe, 1993: 4-5), önemli görevler düşmektedir.

Uluslararası alanda, uluslararası sivil kuruluşlara da yine önemli görevler düşmektedir. Bu bağlamda, çocuk işçiliği ile ilgili mücadele konusunda, uluslararası işçi ve işveren kuruluşları yanında, 1986 yılında sokak çocukları için kurulmuş olan Childhope ve 1990 yılında Asya'da turistlerin seks sömürüsüne karşı çocukları korumak için kurulan ECPAT'ın çalışmalarından bahsetmek gerekir (World of Work, 1993: 9).

Uluslararası finans kuruluşları da, kredi verirken çocuk işçiliği konusunu gündeme getirmelidirler. $\mathrm{Bu}$ kredilerin eğitime, fakirliği önlemeye, istihdam yaratmaya ve iş yasalarının uygulanmasına yönelik olmasına özen gösterilmelidir.

\subsubsection{Daha Fazla Araştırma}

Çocuk işçilerle ilgili veriler kıttır. Çocuk işçiliği sorununa etkili çözümler getirilmek isteniyorsa, ulusal ve uluslararası veri toplama ve analiz etme sistemleri kurulmalı ve değerlendirilmelidir.

Çocuk işçiliği ile ilgili araştırma yapılırken, çocuk işçiliğinin unutulmuş ve "görünmez" alanlarına da özellikle dikkat edilmelidir. Tarım işlerinde çalışanlar ve hizmetçilik kapsamında yapılan işler bunlar arasındadır.

Çalışan çocukların kendi durumlarına ilişkin değerlendirmelere ve koşullarının iyileştirilmesine yönelik önerilerin geliştirilmesine, etkin biçimde katılımı sağlanmalıdır (UNICEF, 1997: 3; ILO, 1996a: 14).

Kısaca, çocuk işçiliği konusunda daha fazla araştırma yapılmalı, çocuk işçiliğinin ekonomik, sosyal ve kültürel nedenleri ortaya konmalı ve sona erdirilmesine yönelik yeni politikalar oluşturulmalıdır.

Çocuk işçiliği ile ilgili araştırmaların kapsamına, çocuk işçiliğinin çözümüne yönelik uygulanan politikaların sonuçları (feedback) da katılmalıdır. Eski deneyimler değerlendirilerek yeni politikalar oluşturulmalı ve uygulanmalidir.

\subsection{Ulusal Mücadele}

Çocuk işçiliği ile ulusal mücadelede; veri toplamak ve araştırma yapmak, eylem için öncelikli sektör ve meslekleri seçmek, toplumun duyarlılığını artırmak, yasal ve kurumsal kapasiteyi geliştirmek, eğitim ve sağlık olanakları sağlamak, fakir ailelerin ve çocukların refahını artırmak gerekmektedir (World of Work, 1996a: 17).

Ulusal politika ve programlarda, çocuk işçiliği ile ilgili ulusal hedefleri belirlemeye, problemin içeriğini tanımlamaya, öncelikli grupları tespit etmeye, müdahale araçlarını belirlemeye ve mücadeleye katılacak kurumsal aktörleri tayin etmeye önemle dikkat edilmelidir.

Çocuk işçiliği ulusal kalkınma planlarının önemli bir parçası olmalıdır. Çünkü çocuk işçiliği fakirlik ve işsizlik ile yakından ilişkilidir.

Çocuk işçiliği ile mücadele bürokratik ve teknokratik bir mücadele değildir. $\mathrm{Bu}$ mücadele diyalog, eğitim ve bilgi paylaşımını içeren bir süreçtir. Kamuoyunu bilinçlendirmek çok önemlidir. Eğer toplum çocuk işçiliğini tüm kesimleriyle bir problem olarak benimser ve mevcut veya alınacak diğer tedbirler daha kolay uygulama şansı bulacaktır (ILO, 1996b: 99-103).

\subsubsection{Problemi Tanımak ve Kabullenmek}

Çocuk işçiliği ile mücadelede ilk adım, çocuk işçiliğinin boyutlarını görmek ve bunu bir sorun olarak kabullenmektir.

Çocuk işçiliğinin boyutlarını tespit ederken, özellikle ev hizmetleri, tarım, küçük işletmeler ve enformel sektörde çalışan çocuklara ulaşılmalıdır. 


\subsubsection{Kaтиоуипu Harekete Geçirmek}

Soruna taraf olan kamu ve özel tüm kesimler, özellikle hükümetler, iş̧̧i ve işveren kuruluşları, sivil kuruluşlar ve diğer gruplar (eğitimciler, adalet mensupları, medya vs.) çocuk işçiliği konusunda bilgilendirilmeli ve duyarlı hale getirilmelidir. İnsan hakları ve çocuk hakları ile ilgili baskı grupları harekete geçirilmelidir. Kamuoyu duyarlı hale getirilerek, çocuk işçiliğinin kabullenilmesi ve hoş görülmesi engellenmelidir.

Birçok aile reisinin, kendisi de çocukluk döneminde çalıştığ için çocukların çalışmasını, bir sosyalleşme süreci, meslek ve yetenek kazanma olayı olarak algıladığı bilinmektedir. Bazı aydınlar ve politikacılar da çocuk iş̧iliğini bir problem olarak değil, az gelişmişlikten kaynaklanan problemlere karş1 bir çözüm olarak görmektedirler. Bunlara göre, özellikle yoksul ailelerin hayatlarını devam ettirmesi için ve eğitim alanında kamu sektörünün yetersizliğinden dolayı, çocukların çalışması bu alandaki boşlukları doldurması açısından- faydalıdır (ILO, 1996a: 17). Toplumdaki bu çeşit yargıların değişmesi için de çaba sarf edilmelidir.

Çocuk işçiliği ile mücadele konusunda yaşanan diğer bir zorluk da toplumun, çocukların yaşadığ 1 problemleri bilmemesidir. Birçok durumda çocukların çalışması, çocuk iş̧̧iler ile işverenleri ve ustaları arasında saklı bir olaydır. Özellikle iş̧i ve işveren kuruluşları, sivil kuruluşlar ve medya, çocuk işçiliğinin görünmeyen (öteki) yüzünü ortaya çıkarmalı, kamuoyunun bilgisine ve dikkatine sunmalıdır.

\subsection{3. Ĕ̈itim}

Eğitim ve okul çocuk işçiliği ile mücadelede en önemli araçlardır. Okul çocuğun, en azından fazla çalışmasını veya tam gün çalışmasını önleyebilir.

Okumuş çocuklar haklarından haberdar olduğundan kolay kolay sağlığına ve güvenliğine aykırı tehlikeli işlerde çalışmayı kabul etmezler. Eğitimli insanlar gelecekte daha bilinçli ve sağlıklı nesiller oluşturdukları için gelecekte çocuk işçiliğini önlemede etki etmektedirler. Eğitilmiş insan daha üretkendir. Eğitim, refaha ve ekonomik gelişmeye hizmet eder. Kısaca eğitimin, sosyal, toplumsal ve kişisel getirisi çok fazladır. Eğitimin bu getirisi, özellikle yoksul aileler için çok daha fazladır.

Ekonomik kalkınmanın en önemli parçasının, insan faktörü ve nitelikli işgücü olduğu göz önüne alınırsa, eğitim sektörüne yapılacak yatımların artııılmasının gerekliliği net olarak ortaya çıkmaktadır. Bu yatırımların planlanması sırasında, ülkenin ihtiyaç duyduğu işgücünün hangi alanlarda olduğunun belirlenmesi şarttır.

Çocuk işçiliği ile mücadelede hükümetlere düşen en önemli görev, başta temel eğitim olmak üzere eğitime gerekli finansal kaynağı ayırmaktır. Ne yazık ki özellikle fakir ülkelerde, silahlanmaya geniş miktarlarda kaynak aktarılırken, eğitime düşen pay çok küçük kalmaktadır.

Eğitim olanakları hem içerik hem de süre açısından geliştirilmelidir. Süre yönünden eğitimin hem ileriye hem de geriye doğru geliştirilmesi gerekmektedir. Yani zorunlu temel eğitim, ilkokul sonrası dönemde olduğu kadar ilkokul öncesi döneme doğru da geliştirilmelidir.

Kız çocuklarının ve kadınların eğitimine, en az erkeklerde olduğu kadar önem verilmelidir.
Eğitim sürecinde, okulları çekici hale getirmek ve okulların kalitesini yükseltmek büyük önem taşımaktadır. Öğretmenlerin sayı ve kalitesi de yükseltilmelidir.

Çocuklara ve ailelerine, okula devamın yaratacağı doğrudan ve dolaylı masraflar katlanabilir duruma getirilmelidir (United Nation Children's Fund, 1997: 67-68). Okul malzemeleri için yapılan harcamalar, ulaşım masrafları gibi doğrudan masraflar yoksul aileler için büyük yük oluşturabilmektedir. Bunların en aza indirilmesi ve yoksul çocuklara okullarda yiyecek ve giyecek verilmesi büyük yararlar sağlayabilir.

Çocukların okula devamı nedeniyle yoksul ailelerin mahrum kaldığı çocukların çalışma olanakları ve gelirleri de okumanın dolaylı maliyeti olarak dikkate alınmalıdır. $\mathrm{Bu}$ amaçla, kırsal yörelerde mevsimlik istemlere uyulmalı, okul saatleri esnekleştirilmeli ve ailelere doğrudan ekonomik yardım sağlanmalıdır (Bulutay, 1995: 24-25).

Aslında ne çocukların ne de ailelerin temel eğitime karşı pek fazla direnmeleri söz konusu olmamaktadır. Eğitimde asıl sorun, devletin talepleri yerine getirememesi, kırsal kesimde ve kent banliyölerinde yeterli eğitim imkânlarını sağlayamamasıdır. 1989-1990 verilerine göre, 116 ülkenin 1/3'ü eğitimden çok orduya (silahlanmaya) harcama yapmıştır. Eğitime ayrılan payın azlığında, ekonominin fakir yapısı ve yapısal dönüşüm politikalarının etkisi olsa da yukarıdaki olguyu da unutmamak gerekir. ILO'nun desteğiyle yürütülen IPEC (International Project and Education System) çalışmalarında görülmüştür ki (ILO, 1996a: 23) ekonomik ve fiziksel olarak girilebilir olsa ve gelecekte istihdam olanağı ve ümidi verse, fakir aileler çocuklarını okula göndermede çok fazla fedakârlık göstermektedirler.

Temel eğitimle birlikte, mesleki ve teknik eğitim ve çıraklık eğitimi yaygınlaştırılmalıdır. Formel çıraklık sistemi, işverenlerin istismarına izin vermeyecek şekilde gözden geçirilmeli, enformel çıraklar da formel çıraklık sistemine dahil edilmelidir.

Okul müfredatlarına, çocuk işçileri tehlikeden korumaya yönelik dersler (bilgiler) konulmalıdır (Beguele ve Myers, 1995: 119-141).

Çocuklar, aileler ve öğretmenler, çocuk hakları konusunda eğitilmeli, çocuk iş̧̧iliğinin uzun dönemdeki maliyeti, sonuçları ve muhtemel alternatifleri anlatılmalıdır.

Çocuk işçiliği ile mücadele edenlerin de eğitilmeleri gerekmektedir. Bu bağlamda, ilgili bakanlık bürokratları, iş müfettişleri, işçi ve işveren sendikaları, sivil kuruluş temsilcileri ve öğretmenler ilk akla gelen gruplardır.

\subsubsection{Toplumun Refahını Artırmak}

Yapılan araştırmalar, çocukların aile gelirine katkıda bulunmak için çalışmak zorunda olduğunu ortaya koymaktadır. $\mathrm{Bu}$ nedenle, öncelikle ailelerin gelir düzeylerini yükseltecek ekonomik önlemler alınmalıdır. Ekonomik önlemler alınırken; gelir dağılımı, ücret, asgari ücret, istihdam, sosyal güvenlik vb. alanlara sistematik biçimde yaklaşılmalıdır.

Çocuk işçiliğinin sona erdirilmesinin, onların katkılarının önemsiz hale gelmesine bağlı olması üzüntü vericidir. Ancak 
ülkede verimlilik ve gelir düzeyi düşük oldukça, çocukların çalışması kolaylıkla engellenemeyecektir.

Gelir artışı kadar onun hakça dağıtımı da önemlidir. Yapılan araştırmalar bu konuda Türkiye'de durumun hiç de iç açıcı olmadığını göstermektedir. Son yıllarda mali piyasalarda oluşan büyük rantların, gelir dağılımını daha da bozduğu bilinmektedir. Ücretlerde yaşanan büyük farklılıklar da bu alandaki bir diğer olumsuzluktur (Bulutay, 1995: 21).

Uzun erimde, aile fertlerinin (yetişkinlerin) gelir ve istihdamlarını artırıcı politikalar oluşturulmalıdır.

Ancak kısa erimli olarak da, sosyal yardım ve sosyal destek sistemlerinin geliştirilmesi gereklidir (Anker ve Melkas, 1996: 21; World of Work, 1996b: 21).Örneğin parasız yatılı okullar yaygınlaştırılmalı ve ailelere çocuklarının eğitimi için sosyal yardım uygulamaları yapılmalıdır. Böylece çocuğun bir işte çalışması yerine, örgün eğitime katılması ve geleceğe sağlıklı bir biçimde hazırlanması mümkün olabilir (Kahramanoğlu, 1994: 59).

Çocuk işçiliği ile mücadelede doğrudan ekonomik destek faaliyetlerinde kullanılan paraların doğru insanlara mı gittiği, maliyetinin sosyal faydasından daha fazla mi olduğu şeklinde sorularla karşılaşılmaktadır. ILO'nun yaptığ 1 bir araştırma (ILO, 1996a: 21), bazı problemleri olsa da bu uygulamanın başarılı olduğunu göstermiştir. Ancak bu yardımlar sürekli ve kalıcı nitelikte olmalıdır.

\subsubsection{Mevzuat Oluşturmak ve Uygulamak}

Hemen hemen her ülkede, çocuklarla ilgili koruyucu mevzuat bulunsa da birçok ülkede bu hükümlerin hayata geçirilmediğine şahit olunmaktadır. Çocuk işçiliği konusunda ulusal mücadelede, bir taraftan çağdaş yasaları hayata geçirmek diğer taraftan mevcut yasaları etkili bir şekilde uygulamak ve denetlemek gerekmektedir.

Yasal düzenlemeler geliştirilirken, çocukların çalışma süresinin (günlük ve haftalık), sağllk ve güvenlik tedbirlerinin, yetişkinlerden farlı ve çocukların lehine olmasına özen gösterilmelidir.

Çocuk işçi çalıştırması ve eğitimle ilgili yasalar, amaçları bakımından birbiriyle tutarlı olmalı ve bu yasalar pratikte birbirini destekleyici tarzda uygulanmalıdır. Çocuk işçiliği ile ilgili ulusal yasalar 1989 sayılı Çocuk Hakları Sözleşmesi ve ilgili ILO sözleşmelerinin (özellikle 138 Sayılı ILO Sözleşmesi) hem özüyle hem de sözüyle uyumlu olmalı ve yasalar tüm çocukları kapsamalıdır.

Çocuk işçilerle ilgili denetim mekanizmasının da yasaklayıcı ve cezalandırıcı niteliği terk edilip, geliştirici, yardım edici, öğretici ve uyarıcı nitelikleri öne çıarılmalıdır. Bu bakımdan, işverenler ve çalışanlar, yasa ve kurallar konusunda bilgilendirilmeli ve sorunun önemi doğrultusunda bilinçlenmelerinin sağlanması gerekmektedir.

Eğitimi bitirme yaşı ile çalışmaya başlama yaşı arasındaki boşluk doldurulmalıdır. Çalışmaya başlama yaşı, zorunlu eğitimi bitirme yaşından küçük olmamalıdır (ILO, 1996a: 22).

\subsection{6. Çocuk Iş̧̧̧ilerin Yerine Yetişkin Isş̧̧ileri Istihdam}

Çocuk işçiliği ile mücadelede atılması gereken bir diğer adım da, çocukları çalışma yerine okula teşvik edip, halen çocukların yapmakta oldukları işlerde işsiz gençleri (yetişkinleri) ve kadınları istihdam etmektir.

Çalışan çocukların birçoğunun annesinin üretim sürecinin dışında (evde) olduğu, yapılan araştırmalarda ortaya çıkmıştır. Annelerin çalışma hayatının içine girmesi, çocukları çalışmaktan kurtarıp okumalarına fırsat sağlayabilir.

\subsubsection{Ticarette Çocuk Isş̧iliğ̈ine Son Vermek}

Hükümetlerin hem ulusal hem de uluslararası ticarette, çocuk işçiler tarafından üretilen ürünlere karşı tedbir almaları gerekmektedir.

$\mathrm{Bu}$ amaçla; üretilen mal ve hizmetlerin "çocuk emeği kullanılmamıştır" (child labour free) etiketiyle pazara çıkması sağlanabilir (World of Work, 1997a: 14-16). Ayrıca bu konuda, ticari antlaşmalara sosyal içerikli hükümler konulabilir. $\mathrm{Bu}$ anlaşmalar ile çocuk işçi istihdamına izin veren ülkelere ve doğrudan ve taşeron firmalar yoluyla dolaylı olarak çocuk istihdam eden çok uluslu şirketlere karşı tavır alınabilir.

Hükümetler sadece kendi sınırları içinde değil, ülke dışında da çocuk istihdam eden vatandaşlarına (uyruklarına) sıkı bir düzenleme getirebilir. Böyle bir uygulamayı halen Avusturya, Yeni Zelanda ve İsveç gibi ülkeler yapmaktadır.

\subsubsection{Tüm Tarafların Birlikte Eylemi (Sosyal İttifak)}

Çocuk işçiliğine karşı büyük bir sosyal ittifak sağlanmalıdır. Hükümetler bu konuda kendilerini sadece çocuk işçiliği ile ilgili yasaları çıkarmakla sınırlandırıp diğer konularda pasif davranmaktadır. İşçi Sendikaları da bu konuda pek donanımlı değillerdir. Bireysel işverenler ise isteksizdirler. İşveren örgütleri de üyelerinin direnişi ile karşı karşıyadır. Çocuk işçiliği ile mücadelede yukarıdaki örgütlerin yanında sivil kuruluşlara da büyük görevler düşmektedir (Olsen, 1996: 77).

Çocuk işçiliği ile mücadeleye medya kuruluşlarının, üniversitelerin, parlamenterlerin, öğretmenlerin ve eğitimcilerin de katılımı sağlanmalıdır.

Çalışan çocukların korunmasını sağlamak, çocuk hakları ve çocuğun refahı ile ilgili ulusal ve uluslararası standartlara uyulmasını denetlemek her şeyden önce hükümetlerin görevidir. Hükümetler temelde üç şekilde olaya müdahil olabilirler (Olsen, 1996: 18) :

(i) Çocuk işçiliği ile ilgili yasalar ve diğer uygulama mekanizmalarını oluşturarak,

(ii) Ulusal çocuk işçiliği politikası oluşturup, önemli sosyal aktörleri buna dâhil ederek,

(iii) Çok fakir ailelerin bile fiziki ve ekonomik olarak ulaşabileceği kamu tarafindan finanse edilen temel eğitim sistemini kurarak.

İşçi sendikaları da çocuk işçiliği ile mücadelede büyük rol oynayabilirler. İşçi örgütleri şimdiye kadar çocuk işçiliği ile yeterince ilgilenmemişlerdir. İşçi örgütlerinin çocuk işçi sorununun çözümüne aktif olarak katılımı sağlanmalıdır. Çünkü istihdamı artırmak, ücretleri yükseltmek ve iş koşullarını geliştirmek, sendikaların en temel amaçlarındandır. Kuşkusuz sendikaların bu hedefleri çocuk işçiliği ile mücadeleye de katkı sağlamaktadır. 
Çocuk işçiliği ile mücadelede sendikaların etkisi, onların örgütlenme seviyesi ile yakından ilgilidir. Birçok ülkede sendikaların, yetişkin işçileri örgütlemedeki yetersizliği göz önüne alınırsa, bu iş epey zor demektir. Zaten çocuk ișçiliğinin de en yoğun olduğu ülkeler de bu ülkelerdir. Sendikalar yedi şekilde çocuk işçiliği ile ilgili mücadeleye katılabilirler (Olsen, 1996: 18-19):

(i) Üyelerini çocuk işçiliği konusunda bilgilendirip, uyarabilirler.

(ii) Çocuk işçiliği konusunda gerekli donanımı sağlayabilirler.

(iii) Çocukların işyerinde yaşadığı kötü muameleyi gün 1şı̆̆ına çıkarabilirler.

(iv) $\mathrm{Bu}$ konuda diğer aktörleri bilgilendirip, motive edebilirler (hükümetler, işverenler vs.). Sendikalar çok etkili bir baskı grubu olarak, sağlık kurumları, öğretmenler, kadın grupları, sivil kuruluşlar, siyasi partiler, medya vs. etkileyebilirler.

(v) Sendikalar çocuklara doğrudan yardımda bulunabilirler(çocukların refahı, eğitimi ve mesleki eğitimi için).

(vi) Sendikalar denetim görevi de görebilirler. Hem yasaların etkili olup-olmadığı hem de uygulanıpuygulanmadığını kontrol edebilirler.

(vii) Sendikalar üyelerini hem bu konuda uyarabilirler hem de üyelerine iyi bir iş düzeni sağlayabilirler. Böylece üyelerinin çocuklarının, çalışmaya mecbur olmasını önleyebilirler.

İşveren örgütleri de çocuk işçiliği ile mücadeleye aşağıdaki şekillerde katılabilirler:

(i) İşveren örgütleri, üyelerini çocukların gereksinimleri konusunda duyarlılaştırıp ve onları çocuk işgücü ile ilgili yasalar konusunda bilgilendirebilirler. Söz konusu yasaların ihlalini azaltmak için devlet kuruluşlarıyla ve devlet dışı kuruluşlarla yapılan çalışmalara öncülük edebilirler.

(ii) İşveren örgütleri üyelerine, sömürüye dayanmayan personel yönetimi yaklaşımlarının uzun erimde daha karlı olduğunu anlatabilirler. Çünkü insancıl ve sosyal endişeler dışında, çalışarak eğitimsiz kalan çocukların, ileride (yetişkinlik döneminde) üretken ve yaratıcı olması beklenmediği için bu uzun vadede işverenlerin menfaatine de değildir. Çocuk işçiliği işverenlerin ve geniş anlamda tüm toplumun, gelecekte kıt olacak olan insan kaynağını israf etmekten başka bir anlam taşımamaktadır.

(iii) İşveren örgütleri üyelerini, çocuk işçi istihdamının oluşturacağı haksız rekabetin sonuçları konusunda da aydınlatabilirler.

(iv) İşveren örgütleri, üyelerini çocuk işçi istihdam etmelerinden dolayı piyasada oluşacak kötü imaj konusunda da uyarabilirler. Firmaların reklamlara harcadığı para bilinmektedir. Bu firmaların çocuk işçi istihdam etmesinin medyada ve herhangi bir şekilde duyulması onun imajına olumsuz etki edecektir. O zaman büyük firmalara düşen, işçi hakları ve çocuk işçi istihdamı konusunda yüksek standartlar tespit edip, hem kendi bünyesinde hem de taşeron firmalarında bunun uygulanmasını sağlamaktır.

Enformel sektörde faaliyet gösteren küçük işletmelerde çalışan çocukların durumu ne olacaktır? Yine burada işveren örgütlerine önemli görev düşmektedir. İşveren örgütleri küçük ve orta boy işletmelere rekabetçiliği öğretmeli, üretim ve personelini geliştirmesine önderlik ve öncülük etmelidir. Küçük ve orta boy işletmelere yeni ve gelişmiş teknolojileri tanıtmak, kredi olanaklarını geliştirme, eğitim imkânları sağlamak ve bu teknolojileri onlara adapte etmek gerekmektedir (Olsen, 1996: 20).

Saklı olanı ortaya çıkarmak ve bilinmeyeni duyurmak medyanın görevidir. Çocuk işçiliğinin görünmeyen (öteki) yüzü ve çocuk işçiliğinin ortaya çıkardığı zararlar genellikle toplumun gözünden kaçtığ 1 için, çalışan çocukların durumunun gün ışı̆̆ına çıkarılmasında medyaya çok büyük görevler düşmektedir.

Hükümet dışı kuruluşlar (sivil kuruluşlar), yasaları ve yaptırım mekanizmalarını gündeme getirip ve hükümetlere bu yasaların etkin biçimde uygulanması konusunda baskı yaparak çalışan çocukların korunmasında etkin rol oynayabilirler. Çünkü gönüllü kuruluşlar:

(i) Aile, toplum ve değerler üzerinde etkili kuruluşlardır. $\mathrm{Bu}$ kuruluşlar toplumdaki popüler kültürün çocukların çalışmaması yönünde değişmesine yardımc1 olabilirler.

(ii) Gönüllü kuruluşlar aynen sendikalar gibi, çocuk işçiliği istismarını kolayca ortaya çıkarabilirler ve kamuoyuna duyurabilirler. Yasaları ve uygulamasını denetleyebilirler.

(iii) Çocuk işçiliği ile ilgili eylem programları yürütebilirler.

Sivil kuruluşların çocuk işçiliği ile ilgili mücadeledeki önemi ortada iken, birçok ülkede sivil kuruluşların çocuk işçiliğine karşı mücadelesine hükümetlerin şüpheyle bakması (Olsen, 1996: 20) düşündürücüdür.

Öğretmenlerin de çocuk ișçiliği ile mücadelede katkısı önemsenmelidir. Çünkü öğretmenler:

(i) Çocuk işçiliği problemini müfredata (gündeme) alarak bu konuda çocukları aydınlatabilirler.

(ii) Öğretmenler, aile ve velilere çocuk işçiliğinin önemini ve tehlikelerini anlatabilirler.

(iii) Öğretmenler, örgütleriyle de bu konuyu gündeme getirip, yoksul aile çocuklarının eğitim sistemine katılmasına yardımcı olabilirler (Olsen, 1996: 21).

\subsubsection{Kurumsal Mekanizma Oluşturmak}

Çocuk işçiliği ile mücadelede, kurumsal mekanizma oluşturmak şarttır (ILO-IPEC, 1994: 33). Bunun için hükümetler öncelikleri tespit etmek, bakanlıklar ve diğer kuruluşlar arasındaki ilişkileri geliştirmek ve koordine etmek, tüm kesimlerin bu mücadeleye katılımını sağlamak ve pilot bölgelerde eylem programları uygulamak için özel birimler oluşturulmalıdır (ILO, 1996a: 21).

Tayland, Kolombiya ve ülkemizde böyle birimler oluşturulmuştur. Türkiye 1992 yılında Çalışma ve Sosyal Güvenlik Bakanlığı bünyesinde Çalışan Çocuklar Birimi kurulmuştur.

Türkiye'de işveren ve işçi kuruluşları da çocuk işçiliği konusunda kurumsal mekanizma oluşturmuşlardır. Nitekim Türk İşçi Sendikaları Konfederasyonu (Türk-İş) bünyesinde bu maksatla Çalışan Çocuklar Bürosu kurmuştur. 


\subsubsection{Eylem Programları Uygulamak}

Çalışan çocuk işçileri korumak, tehlikeli işlerden çocukları alıkoymak ve çocukların eğitime ve mesleki eğitime katılmalarını sağlamak için eylem programları yapmalı ve uygulanmalıdır.

$\mathrm{Bu}$ programlar ile çocukların iş ve yaşam koşulları geliştirilmelidir. Ayrıca uygulanan programların sonuçları değerlendirilmeli, bu sonuçlar ışı̆̆ında yeni programlar yapılmalıdır. Tecrübe edilmiş yeni programlar da daha geniş biçimde uygulanmalıdır (ILO-IPEC, 1994: 32).

\subsubsection{Rehabilitasyon}

Kölelik, fahişelik gibi kabul edilemez istihdam ilişkileri içinde çalışanlar ve sokak çocukları, bu işlerde çalışmaktan alıkonulduktan sonra rehabilite edilmelidir. Çocuk terapistleri tarafindan yapılacak rehabilitasyondan sonra çocukların normal hayata intibak etmesi sağlanmalıdır.

\section{Kısa ve Uzun Vadede Mücadele}

Çocuk işçiliği probleminin çözümüne nereden başlanılmalıdır? Bu konuda elimizde mevcut insan, araç ve parasal kaynakları nasıl değerlendirmeliyiz? Bu önemli bir sorundur. ILO'nun deneyimleri de dikkate alınarak çocuk işçiliği ile mücadele iki aşamalı olarak yürütülmelidir.

\subsection{Rehabilitasyon}

Kısa erimde eldeki sınırlı kaynaklar kölelik, borç köleliği ve çocuk fahişeliği ile mücadeleye, tehlikeli iş ve endüstrilerde çalışan çocukları ve çok küçük yaştaki çocukları (özellikle de kız çocukları) korumaya ayrılmalıdır. Dolayısıyla eldeki kıt kaynakları, en kabul edilemez biçimde istihdam edilen çocukların çalışması ile mücadeleye ayırmalıyız (Forastieri, 1992: 8).

ILO'nun da kısa erimde hedefí, zorunlu çalışma, kölelik gibi çalışma ilişkilerinden, maden ve taş ocakları gibi endüstrilerden ve fuhuş ve pornografi gibi işlerden çocukları alıkoymak ve çok küçük yaştaki çocukların (12 yaş altı) çalışmasını önlemektir (ILO-IPEC, 1994: 27; World of Work, 1997b: 23).

Çocukların tehlikeli işlerde ve sömürücü biçimlerde çalıstııılmalarına hemen son verilmelidir. Kölelik, zorla çalıştırma, ticari amaçlı cinsel sömürü ve çocuğun bedensel, toplumsal, zihinsel, duygusal ya da ahlaksal gelişimini engelleyen işler dâhil olmak üzere, çocuk çalıştırılmasının tehlikeli ve sömürücü biçimlerine hiçbir şekilde anlayış gösterilmemeli ve bu olguya son vermek için gerekli önlemler acilen alınmalıdır (UNICEF, 1997: 22).

Ne yazık ki çocuk işçiliğinin en yaygın olduğu ülkeler, yukarıdaki problemlerle karşı karşıyadır. Bunun için çocuk işçiliği ile mücadeleye, çocukların onur, ahlak, güvenlik, sağlık ve eğitimine en çok zarar veren işlerden onları kurtarmaktan başlamalı, daha sonra çocuk işçiliğine tamamen son verilmelidir (ILO, 1996a: 15). Ancak hangi işlere öncelik verileceği iyi seçilmelidir.

Mevcut koşullar değişmedikçe, çocuklar daha uzun bir süre çalışacaklarına göre, çocukları çalışırken korumak kısa erimli mücadelenin bir diğer yönünü oluşturmaktadır. $\mathrm{Bu}$ durumda yapılması gereken, çalışan çocukların çalışma koșullarını iyileștirmek üzere projeler geliștirmek ve yaşama geçirmektir (Karabulut, 1996: 46).

\subsection{Uzun Vadede Çocuk İşçiliği İle Mücadele}

Çocuk işçiliğine karşı mücadelenin ikinci yönünü, çocuk işçiliğinin tamamen sona erdirilmesi oluşturmaktadır. $\mathrm{Bu}$ konuda yapılacak ilk iş, çocukların çalışıı̆ı işleri ve işyerlerini, -görünmeyeni- görünür hale getirmek ve kamuoyunun bilgisine sunmaktır. Çocuk işçiliği konusunda araştırmalar yapıp, çocukların hayatına, fiziki, akli ve sosyal gelişimine tehlike oluşturan faktörleri ortaya çıkarmak gerekmektedir.

Ancak burada, hangi önlemlerin alınacağı, hangi işlerin, hangi mesleklerin ve hangi endüstrilerin çocuğa daha fazla zarar vereceğine karar verilmelidir. Çocuğa orta ve uzun vadede hangi işlerin daha fazla zarar verebileceği, değişik branşlardaki uzmanların çalışması ile bulunmalıdır. Çünkü çocuk iş̧̧iliği probleminin çözümü tümüyle teknik değildir. Çözüm sosyal, psikolojik, hukuki vs. koordineli bir çalışmayı gerekli kılmaktadır (ILO, 1996b: 21).

Orta ve uzun vadede ILO'nun hedefi, çocukların çalışırken korunması ve çocuk iş̧̧iliğinin tamamen ortadan kaldırılmasıdır (ILO-IPEC, 1994: 27).

Uzun erimli mücadelenin çerçevesini, temel sorunların çözümü yönünde sosyo-ekonomik önlemlerim alınması, sosyal ve ekonomik gelişmenin sağlanması, çocukların ve gençlerin korunmasını amaçlayan yasal düzenlemelerin uluslararası normlar dikkate alınarak, ülke gerçeklerine ve gereksinimlerine uygun olarak hazırlanması ve denetlenmesi çizmektedir (Karabulut, 1996: 46).

Çocuk iş̧̧iliği yoksulluk, eşitsizlik, işsizlik, eğitim sisteminin başarısızlığ birlikte değerlendirilmelidir. Kalkınma plan ve programları yapılırken, özellikle ekonomik gelişme, adaletli gelir dağılımı ve insan kaynaklarının geliştirilmesi ile ilgili öğeler birlikte düşünülmelidir.

\section{Sonuc ve Değerlendirme}

Çocuk emeğinin üretim amaçlı kullanılması anlamını taşıyan çocuk işçiliği bilgi çağı olan günümüzde de güncelliğini korumaktadır (Tunçcan, 2000: 257). Küreselleşen dünyada çocuk iş̧iliği sadece daha yoğun çocuk iş̧̧i istihdam eden gelişmekte olan ülkelerin değil, bu sorunu önemli ölçüde çözmüş olan gelişmiş ülkelerin de problemidir. Çünkü çocuk işçiliği doğrudan ve dolaylı etkilerini gelişmiş ve gelişmekte olan tüm dünyada göstermektedir. Onun için çocuk iş̧̧iliği hepimizin ortak sorunudur.

Çocuk işçiliği insan hakları ile yakın ilgilidir. Çünkü çocuklar, zorla veya zorunlu olarak, çalışma hayatının içinde yer almaktadırlar. En temel insan haklarından olan, çocukluklarını yaşayamamakta ve geleceğe hazırlanmak için eğitim imkânlarından faydalanamamaktadırlar.

Çocuk iş̧̧iliği zaten kıt olan yetişmiş insan kaynağının, hoyratça israfının da en belirgin örneğini oluşturmaktadır. $\mathrm{Bu}$, kısa dönemde çocuk iş̧i istihdam eden işletmelere ve ülkelere geçici görüntüde bazı avantajlar sağlasa da uzun dönemde onların da zararına işlemektedir. Onun için çocuk işçi istihdamı politikası, gelecekte telafisi mümkün olamayan yanlı bir uygulamadır. 
Yapılan araştırmalar çocuk işçilerin çoğunun gelişmemiş ülkelerde bulunduğunu göstermektedir.

Çocuk işçilerin çoğu, tarım sektörünün ağırlığından dolayı tarımda ve kırsal kesimde çalışmaktadır. Ancak kırsal kesimden kente doğru yaşanan göç dalgası, çocuk işçiliğinin merkezini metropollerin banliyölerine kaydırmaktadır.

Çocuk işçiliği gelişmekte olan bazı ülkelerde artan bir eğilim sergilerken, gelişmiş ve gelişmekte olan bazı ülkelerde azalma eğilimindedir.

Çocuk işçiliğinin en önemli nedeni yoksulluk olsa da tek nedeni değildir. Çocuk işçiliğinin ekonomik nedenleri dışında, sosyal ve kültürel nedenleri de bulunmaktadır. Ekonomik nedenler arasında, yoksulluk, enformel ekonomi, KOBİ'ler, çocuk işgücünün maliyeti ve bazı işlerin çocuklara daha uygun olmasını sayabiliriz.

Çocukların çalışma nedenleri arasında, nüfus atışı, düzensiz kentleşme ve tüm boyutlarıyla eğitimsizlik sosyal sebepleri oluşturmaktadır. Çocuk ve çocuk emeğine bakış, sosyalleşmenin algılanışı, enformel çıraklık ve çocuğa karşı ayrımcılık da çocuk işçiliğinin kültürel nedenlerini oluşturmaktadır.

Çocuk işçiliği kendisine bir kısır döngü oluşturmaktadır. Çünkü çocukların çalışması eğitimsizliği, düşük verimi ve işsizliği, işsizlik düşük geliri ve yoksulluğu, yoksulluk da yeniden çocuk işçiliğini doğurmakta, engellenemez ise, bu kısır döngü devam edip gitmektedir.

Sosyo-ekonomik sınıf ile bağlantısı bulunan yoksulluk çocuk işgücü arzını oluşturmakta ancak çocuk işgücüne olan talep devam ettiği sürece de bu sorunun ortadan kalkmayacağı görülmektedir (Yıldız, 2007: 58).

Çocuk işçiliği problemi çözümsüz değildir. Ancak problemin çözümü hem çok taraflı hem de uzun bir süreci gerekli kılmaktadır. Aşağıda çocuk işçiliğine ilişkin yapılması gereken öneriler yer almaktadır:

(i) Çocuk işçiliği tüm dünyanın ortak sorunudur. Onun için probleme ulusal boyutta olduğu kadar uluslararası boyutta da müdahale etmek gerekmektedir.

(ii) Çok uluslu şirketler hem kendi bünyelerinde hem de taşeronları vasıtasıyla çocuk işçi istihdam etmeme konusunda bilinçlendirilmeli, bu konuda uluslararası düzenlemelere de gidilmelidir.

(iii) Tüm dünyada her insan birer tüketici olarak, çocuklar tarafından üretilen ürünleri satın almayarak çocuk işçiliğine karşı mücadele edebilir.

(iv) ILO, çocuk işçiliği ile mücadele başat bir rol oynamaktadır. Ancak çocuk işçiliği sadece ILO'nun çözebileceği bir problem değildir. Özellikle diğer BM kuruluşları (UNESCO, UNICEF vs.) ve diğer uluslararası kuruluşlar (işçi ve işveren kuruluşları, sivil kuruluşlar vs.) da bu mücadeleye destek vermelidirler.

(v) Ulusal düzeyde olduğu kadar uluslararası düzeyde de çocuk işçiliği konusunda daha fazla araştırmaya ihtiyaç vardır.

(vi) Ulusal düzeyde çocuk işçiliği ile mücadelede yapılması gereken ilk iş çocuk işçiliğini bir problem olarak tanımak ve kabullenmektir. (vii) Ulusal kamuoyu çocuk işçiliği konusunda bilgilendirilmeli ve duyarlılaştırılmalıdır.

(viii) Eğitim ve okul çocuk işçiliğini sona erdirmede en etkili araçtır. Hem temel eğitim hem de mesleki eğitim yaygınlaştırılmalıdır. Eğitimin doğrudan ve dolaylı maliyetleri, yoksul ailelerin de katlanabileceği duruma getirilmeli, eğitimin kalitesi yükseltilmeli ve gelecekte istihdam olanağı sağlar duruma getirilmelidir.

(ix) Çocuk işçiliğinin en önemli nedenlerinden olan yoksulluğu ortadan kaldırıcı ve toplum refahını artırıcı politikalar oluşturulmalı ve uygulanmalıdır.

(x) Ulusal düzeyde yapılacak diğer önemli bir faaliyet, çocuk işçiliği konusunda uluslararası standartlara da uyum sağlayacak şekilde, mevzuat oluşturmak ve etkin bir biçimde uygulamaktır.

(xi) Çocuk işçilerin yerine yetişkin işçiler istihdam edilmeli, özellikle de kadınların üretime katılmaları sağlanmalıdır.

(xii) Ticarette çocuk işçiliğine son verilmelidir. Sadece ucuz-uysal çocuk işgücü istihdam ederek ticarette haksız rekabet sağlamanın önüne geçilmelidir.

(xiii) Çocuk işçiliğine karşı ülkedeki tüm taraflar birlikte ve koordineli bir şekilde mücadele etmelidir. Bu konuda bir sosyal ittifak sağlanmalıdır. Özellikle hükümetler, işçi ve işveren kuruluşları, sivil kuruluşlar, üniversiteler vs. birlikte hareket etmelidir.

(xiv) Ulusal düzeyde kamu ve özel kuruluşların faaliyetlerini koordine etmek, ulusal veya bölgesel eylem programlarını hayata geçirmek için kurumsal bir mekanizma oluşturmalı ve güçlendirilmelidir.

(xv) Ulusal ve bölgesel düzeyde eylem programları uygulamak, buralarda kazanılan deneyimleri kullanarak bu programları daha geniş alanlara yaymak gerekmektedir.

(xvi) Çocuk işçiliği ile mücadelede, yoksul ailelerin çocuklarını çalışma hayatından alıkoyup okula gönderilebilmesi için, bu ailelere doğrudan ekonomik yardım da yapılmalıdır.

(xvii) Çok kötü şartlarda ve istihdam biçimlerinde çalışan çocuklar çalışmaktan alıkonulduktan sonra, normal hayata döndürülmeden önce ihtiyac1 olanlar rehabilite edilmelidir.

(xviii) Eldeki kıt kaynaklarla çocuk işçiliği ile mücadeleye nereden başlanılmalıdır? ILO'nun da tavsiye ettiği gibi önce kısa dönemde, kabul edilemez istihdam biçimlerinde çalışan çocuklara (kölelik, fahişelik, uyuşturucu ticareti vs. ), ağır ve tehlikeli işlerde çalışanlara (maden ve taş ocaklara vs.) ve en korumasız gruplara (12 yaşın altındakiler ve kız çocukları) ulaşılmalıdır. Ayrıca bu dönemde, çalışan çocuk işçilerin çalışmaktan alıkonulana kadar işyerinde korunması da sağlanmalıdır.

(xix) Orta ve uzun dönemde ise çocuk işçiliğinin tüm boyutları ile sona ermesi konusunda politika oluşturulmalı ve uygulanmalıdır.

\section{Kaynakça}

ASPB (2013). Ulusal Çocuk Haklart Strateji Belgesi ve Eylem Planı 2013-2017. Ankara: Aile ve Sosyal Politikalar Bakanlığı. 
Alliance (2017). Global Estimates - Child Labour, 2017. (Erişim: 03.02.2018) http://www.alliance87.org/2017ge/childlabour\#!section $=0$

Anker, R., \& Melkas, H. (1996). Are economic incentive programmes effective?. World of Work. The Magazine of ILO, (16).

Avşar, Z., \& Öğütoğulları, E. (2012). Çocuk İşçiliği ve Çocuk İşçiliği ile Mücadele Stratejileri. Sosyal Güvenlik Dergisi, 1, 9-40.

Beguele, A., \& Myers, W. (1995). First Thing First In Child Labour . Cenevre: UNICEF-ILO.

Bulutay, T. (1995). Türkiye'de Çalışan Çocuklar (Child Labour In Turkey). Yayın No: 1840. Ankara: DIE-ILO.

ÇSGB (2017). Çocuk Iş̧̧̧iliği İle Mücadele Ulusal Programı. Ankara: Ayrıntı Basımevi.

Efe, H., \& Uluoğlu, S. A. (2015). Dünyada Çocuk İşçiliğiyle Mücadelede Gelinen Nokta ve Geleceğe Dair Bazı Öngörüler. Eğitim Bilim Toplum, 13(51), 46-72.

Forastieri, V. (1997). Child Labour. World Health.

ICFTU (1996). No Time To Play Child Workers In the Global Economy. Brüksel.

İlik, B., \& Türkmen, Z. (1994). Çocuk Isşçiliğinin Temel Nedenlerinden Birisi Olan Göç Araştırma Projesi Dokümanı. Ankara: ILO Yayınları.

ILO (1996a). Child Labour: What is to be done?. Cenevre: International Labour Organization.

ILO (1996b). Child Labor : Targeting the Intolerable. Cenevre: International Labour Organization.

ILO-IPEC (1994). Action for the Elimination of the Child Labour (Overwiev of the Problem and Response). İtalya.

Kahramanoğlu, E. (1994). "Sanayide Çocuk İşçiliği", Türkiye'de Çocuk İsgücü. Ankara: TİSK.

Kamm, L. (1995). Child labor feeds global market profits. National Catholic Reporter, 31(13).

Karabulut, Ö. (1996). Türkiye'de Çalışan Çocuklar. İstanbul: Friedrich Ebert Vakfi.

Karabulut, Ö. (1999). Çocuk İşçiliğinde Mevcut Durum, Sendikal Eğitim Atölye Çalışmalarl. İstanbul.

Küçükkalay, M., Dulupçu, M., \& Turunç, Ö. (2000). Dünyada ve Türkiye'de Çocuk İşücü İstihdamı ve Sorunlar1. Süleyman Demirel Üniversitesi İktisadi ve Ídari Bilimler Fakültesi Dergisi, 5(1), 103-118.

Olsen, T. (1996). Churhes Fight Overseas Child Labour. Chiristianity Today, 40(12).

Suteliffe, P. (1993). An evil unbearable to human heart, World of Work. The Magazine Of ILO, (4).

Thullen, G. (1994). Forced Labour Human Bondage in Today's World. UNESCO Courier, (10).

Tunçcan, N. (1999). Küreselleşen dünyada çocuk istihdamı. Yüksek Lisans Tezi. İstanbul: İstanbul Üniversitesi.
Tunçcan, N. (2000). Çocuk İşçiliği: Nedenleri, Boyutları ve Küreselleşen Dünyadaki Konumu. Sosyal Siyaset Konferansları Dergisi, (43-44), 243-259.

TÜİK (2006). Çalışan Çocuklar Working Child 2006. Ankara: T.C. Başbakanlık Türkiye İstatistik Kurumu.

TÜİK (2012). Çalışan Çocuklar Working Child 2012. Ankara: T.C. Başbakanlık Türkiye İstatistik Kurumu.

TÜİK (2013). Istatistiklerle Çocuk, 2012. 02 04, 2018 tarihinde Türkiye İstatistik Kurumu: http://www.tuik.gov.tr/PreHaberBultenleri.do?id=13488 adresinden alınd.

TÜİK (2014). Istatistiklerle Çocuk, 2013. 02 04, 2018 tarihinde Türkiye İstatistik Kurumu: http://www.tuik.gov.tr/PreHaberBultenleri.do?id=16054 adresinden alındı.

TÜİK (2016). Ístatistiklerle Çocuk, 2015. 02 04, 2018 tarihinde Türkiye İstatistik Kurumu: http://www.tuik.gov.tr/PreHaberBultenleri.do?id=21521 adresinden alındı.

TÜİK (2017). Istatistiklerle Çocuk, 2016. 02 04, 2018 tarihinde Türkiye İstatistik Kurumu: http://www.tuik.gov.tr/PreHaberBultenleri.do?id=24645 adresinden alındı.

UNICEF (1997). Dünya Çocuklarının Durumu. Oxfordshire, İngiltere: Oxford Universitesi Yayını Waltton Street Oxford, OX26DP.

UNICEF (2006). Önce Çocuklar: Çocuk İşçiliğinin Ortadan Kaldırlmast. 02 03, 2018 tarihinde Unicef: https://www.unicef.org/turkey/dn_2006/_cp41.html adresinden alınd.

United Nation Children's Fund (1997). How Can I Study? Social Education, 61(2), 64-69.

Winner, L. (1996). Langdon Winner, The Destruction of Childhood. Tecnology Review, 99(8).

World of Work (1993). Concerted international action for children. The Magazine of ILO(4).

World of Work (1996a). Action required at the national level. The Magazine of ILO(6).

World of Work (1996b). International action: Standart need reinforcing. The Magazine of ILO(16).

World of Work (1997a). The Sialkot Story: Making villages child labour free. The Magazine of ILO(19).

World of Work (1997b). New weapons against child traficking in Asia. The Magazine of ILO(19).

Yıldız, Ö. (2007). Çalışan Çocuklar: 'Sorun' mu? 'Çözüm' mü? Gaziantep Üniversitesi Sosyal Bilimler Dergisi, 6(2), 57-66. 